\title{
Effect of calcium, potassium and some antioxidants on growth, yield and storability of sweet potato: \\ 1- Vegetative growth, yield and tuber root characteristics.
}

\author{
El-Seifi, S. K. ${ }^{1}$; M. A. Hassan ${ }^{1}$; Sawsan M. H. Serg ${ }^{1}$; U. M. Saif El-Deen ${ }^{2}$ and M. A. Mohamed ${ }^{1}$ \\ ${ }^{1}$ Dept. of Hort., Fac. of Agric., Suez Canal Univ. Ismailia, Egypt. \\ ${ }^{2}$ Veg. Res. Dep., Hort. Res. Inst., Agric. Res. Center, Giza, Egypt.
}

\begin{abstract}
Two field experiments were carried out at El-Bramoon Agricultural Research farm of Mansoura Horticultural Research station, during the two successive summer seasons of 2011 and 2012 on sweet potato (Ipomoea batatas, L.) plants $\mathrm{cv}$. Beauregard. The aim of this study was to study the effect of foliar spray of calcium at $(0,1000$ and $2000 \mathrm{ppm})$, potassium fertilization at $\left(0,48,72 \mathrm{~kg} \mathrm{~K}_{2} \mathrm{O} / \mathrm{fed}\right.$.), and foliar spray of antioxidants (control, ascorbic acid at $200 \mathrm{ppm}$ and salicylic acid at $200 \mathrm{ppm}$ ) on plant growth, yield and its components as well as tuber root characters. The obtained results showed that foliar spray of only $2000 \mathrm{ppm}$ of calcium or with the interaction among $1000 \mathrm{ppm}$ of calcium, potassium fertilization at $72 \mathrm{~kg} \mathrm{~K}_{2} \mathrm{O} / \mathrm{fed}$. and foliar spray of antioxidants as ascorbic acid at $200 \mathrm{ppm}$ or salicylic acid at $200 \mathrm{ppm}$ recorded the highest values of the above-cited indices compared with the control. Positive interaction between foliar spray of calcium and potassium fertilization and foliar spray of antioxidants were often observed.

The best results were obtained by foliar spray of only $2000 \mathrm{ppm}$ of calcium or with the interaction among $1000 \mathrm{ppm}$ of calcium, potassium fertilization at $72 \mathrm{~kg} \mathrm{~K}_{2} \mathrm{O} / \mathrm{fed}$. and foliar spray of antioxidants as ascorbic acid at $200 \mathrm{ppm}$ or salicylic acid at $200 \mathrm{ppm}$.
\end{abstract}

Key words: sweet potato (Ipomoea batatas, L.), foliar spray, antioxidants, ascorbic acid, salicylic acid.

\section{Introduction}

Sweet potato (Ipomoea batatas L.) is a dicotyledonous root crop and a member of the family Convulvulaceae. Moreover, sweet potato is the seventh most important food crop in the worldwide, after wheat, rice, maize, potato, barley and cassava. The primary importance of sweet potato is cultivated in poor regions of the world. It is the fourth most important food crop in developing tropical countries and is grown in most of the tropical and subtropical regions of the earth, where the vine, as well as the roots, is consumed by humans and livestock (Woolfe, 1992).

In Egypt, it is considered a very important popular vegetable crop, it has been generally cultivated for both food and starch manufactures, while the foliage parts and other refuse are utilized in feeding. Great efforts have been directed to improve sweet potato production and quality for the purpose of increasing exported yield. The applied $\mathrm{Ca}, \mathrm{K}$ and antioxidants are among the major factors affecting plant growth and tuber root yields of sweet potato (El-Sayed 1991; Abd El-Baky et al., 2010., Njiti et al., 2013).

Calcium is an essential macronutrient required for plant growth and has been implicated as a factor influencing tuber quality (Lang et al., 1999). Moreover, calcium has attracted much interest in plant physiology and molecular biology because of its function as a second messenger in the signal conduction between environmental factors and plant responses in terms of growth and development (Reddy, 2001), Moreover, $\mathrm{Ca}^{2+}$ plays a pivotal role in membrane stabilization and in regulation of enzymes synthesis e.g. protein-kinase or phosphatase (Schmitz-Eiberger et al., 2002).

Potassium is an essential plant nutrient that plays a very important role in plant growth and development. Its role is well documented in photosynthesis, increasing enzyme activity, improving synthesis of protein, carbohydrates and fats, translocation of sugars, enabling their ability to resist pests and diseases (Dkhil et al., 2011). Also, potassium has an established reputation as a major controlling effect on tuber production in plant and it is the most important nutrient element needed by sweet potato in terms of nutrient uptake per unit area per unit tuber production. Since sweet potato is generally grown on highly weathered and leached soils where available $\mathrm{K}$ status is low, management of $\mathrm{K}$ assumes greatest significance (Byju and George, 2005).

Ascorbic acid (Vit. C) has a wide range of important functions as antioxidant defense, photoprotection, regulation of photosynthesis, affects nutritional cycle's activity in higher plants, electron transport system, as a cofactor for a large number of key enzymes in plants, also developmental senescence, programmed cell death and responses to pathogens (Blokhina et al., 2003).

Salicylic acid (SA) naturally occurs in plants in very low amounts and participates in the regulation of physiological processes in plant such as stomatal 
closure, photosynthesis, transpiration, nutrient uptake, chlorophyll and protein synthesis, inhibition of ethylene biosynthesis, resistance to pathogens plant disease and increased longevity of storage period (Hayat and Ahmad, 2007).

From the foregoing, the present study is very important to evaluate the effects of different rates of calcium fertilizer as foliar spray with different rates of potassium fertilizer as soil application either alone or in combination with some antioxidants; i.e., salicylic acid and ascorbic acid as foliar spray on plant growth, yield and tuber root characteristics of sweet potato plants cv. Beauregard.

\section{Materials and Methods}

Two field experiments were carried out at ElBramoon farm of Mansoura Horticultural Research station, during the two successive summer seasons of 2011 and 2012. The experiments were designed to investigate the effects of some nutrients treatments namely calcium and potassium besides two antioxidants; i.e., ascorbic and salicylic acid along with their interactions, on plant growth, yield and its components, as well as some chemical constituents and tuber roots storability of sweet potato (Ipomoea batatas, L.) cv. Beauregard.

\section{Experimental Soil Analysis:}

Randomized samples were collected from the experimental soil at 0.0 to $50.0 \mathrm{~cm}$ depth, before planting to determine its physical and chemical properties in accordance to the methods of Black (1965) and Jakson (1967), respectively. Data of soil analysis is presented in Table (1):

Table 1. Some physical and chemical properties of experimental soil.

\begin{tabular}{|c|c|c|c|}
\hline Soil properties & Value & Soil properties & Value \\
\hline Physical & & Soluble anions (meq/l) & \\
\hline Coarse sand & $7.71 \%$ & $\mathrm{CL}^{-}$ & 3.56 \\
\hline Fine sand & $18.14 \%$ & $\mathrm{HCO}_{3}$ & 3.20 \\
\hline Silt & $33.65 \%$ & $\mathrm{CO}_{3}^{-2}$ & 0.00 \\
\hline Clay & $40.50 \%$ & $\mathrm{SO}_{4}{ }^{-2}$ & 5.16 \\
\hline Texture & Clay-loam & Soluble cations (meq/l) & \\
\hline Chemical & & $\mathrm{Ca}^{+2}$ & 4.03 \\
\hline Organic matter (\%) & 1.95 & $\mathrm{Mg}^{+2}$ & 1.35 \\
\hline $\mathrm{CaCO}_{3}$ & 4.55 & $\mathrm{Na}^{+}$ & 1.21 \\
\hline E.C. $\left(\mathrm{dsm}^{-1} \text { at } 25^{\circ} \mathrm{C}\right)^{*}$ & 1.12 & $\mathrm{~K}^{+}$ & 5.33 \\
\hline $\mathrm{PH}(1: 2.5 \mathrm{w} / \mathrm{v})^{* * *}$ & 7.91 & & \\
\hline Total - N (\%) & 0.20 & & \\
\hline Available - P (ppm) & 11.72 & & \\
\hline
\end{tabular}

The values are the average of the two growing seasons.

\section{Experimental design and tested treatments:}

The experiments were designed as split-split-plot with 3 replicates. The different rates of calcium occupied the main plots, which subsequently subdivided into 3 sub-plots; each contained one of the potassium rates, while antioxidants treatments were assigned to the sub-sub-plots.

Each sub-sub-plot area $17.5 \mathrm{~m}^{2}$ and contained 5 rows, with $5 \mathrm{~m}$ in length and $0.7 \mathrm{~m}$ in width for each row. The experiment included 27 treatments which were 3 calcium rates (tap water, 1000 and $2000 \mathrm{ppm}), 3$ potassium rates $(0,48$ and $72 \mathrm{~kg}$ $\mathrm{K}_{2} \mathrm{O} /$ fed.) and 3 rates of antioxidants (tap water, ascorbic acid at $200 \mathrm{ppm}$ and salicylic acid at 200 ppm).

\section{Time and method of treatments:}

- Calcium: Calcium citrate $(21 \%)$ was used as source of calcium at the rates of $0,4.76$ and 9.52 g. calcium citrate were dissolved in litter distilled water to obtain calcium at the rates of 0,1000 and
2000 ppm, respectively and applied to plants as foliar spray at 60 and 90 days after sowing.

- Potassium: Potassium sulphate (48\%) was used as source of potassium at the rates of 0,48 and 72 $\mathrm{kg} \mathrm{K}_{2} \mathrm{O} /$ fed., were obtained from 0,100 and 150 $\mathrm{kg}$ potassium sulphate, respectively were equally divided and applied at planting and 30 days later.

- Antioxidants: Antioxidants were obtained from El Nasr Pharmaceutical Chemicals Co. Egypt and used at the rates of $0.2 \mathrm{~g}$. ascorbic was dissolved in litter distilled water and $0.2 \mathrm{~g}$. salicylic acid was dissolved in alcohol and added to litter distilled water to obtain the rates of ascorbic acid at $200 \mathrm{ppm}$ and salicylic acid at $200 \mathrm{ppm}$, applied to plants as foliar spray at $15,45,75$ days after sowing.

\section{Cultural practices:}

Sweet potato stem cuttings, about $20 \mathrm{~cm}$ length, were planted on the third top of slope ridges, at $25 \mathrm{~cm}$ apart, on the 20,21 of April of both growing seasons of the study. Growing plants were 
fertilized with $300 \mathrm{~kg} / \mathrm{fed}$. Calcium super phosphate $\left(15.5 \% \mathrm{P}_{2} \mathrm{O}_{5}\right)$ and $200 \mathrm{~kg} / \mathrm{fed}$. ammonium sulphate $(20.5 \% \mathrm{~N})$. Other inter-cultural practices including weed and pest control will be followed as instructed by the Ministry of Agriculture. Harvesting of tuber roots was done on the 23, 24 of August (125 days after planting) in both seasons.

\section{Recorded data:}

\section{1- Vegetative growth parameters:}

Five representative plants were randomly picked up from sub-sub-plot, 100 days after planting to measure, plant length, number of branches/plant, leaf area/plant (according to the method of Koller, 1972), dry weight per plant and total chlorophyll a + $\mathrm{b}$ (according to the method of Moran, 1982).

\section{2- Yield and its components:}

At harvest, 125 days from planting, all tuber roots of plants of each sub-sub-plots were digged up, classified into two categories; i.e., marketable and non- marketable roots then weighted to determine the total yield per feddan (tons). Marketable roots have a diameter of 3.5 to $6.5 \mathrm{~cm}$, while non-marketable roots have a diameter of less than $3.5 \mathrm{~cm}$ or more than $6.5 \mathrm{~cm}$ according to the method described by Grang (1963). In addition, plant yield as tuber root number and weight $(\mathrm{kg})$ was determined.

\section{3- Tuber root characters:}

Tuber root samples (each of 10 storage roots) were randomly chosen at harvesting time from each treatment, to determine average tuber root weight $(\mathrm{g})$, length $(\mathrm{cm})$, diameter $(\mathrm{cm})$ and shape (length/diameter). Dry matter percentage was determined by drying $100 \mathrm{gm}$ fresh tuber roots at 70 ${ }^{\circ} \mathrm{C}$ for until constant weight is obtained.

\section{Statistical analysis:}

All recorded data were subjected to statistical Analysis of Variance and least significance differences (Duncan's) at 0.05 level of probability were used to separate means, as mentioned by Sndecor and Cochran (1980).

\section{Results and Discussion}

\section{1- Vegetative growth parameters:}

Data presented in Table 2 show that vine length, leaf area, canopy dry weight/plant and total chlorophyll content of leaves were significantly increased, in both growing seasons, in response to foliar spray of calcium at 2000 ppm compared with the control except for number of branches/plant, in the first growing season, and there were no significant differences between foliar spray of calcium at 1000 or $2000 \mathrm{ppm}$ on number of branches/plant in both growing seasons and canopy dry weight/plant in the first growing season. Also there were no significant differences between foliar spray of calcium at $1000 \mathrm{ppm}$ and the control on vine length in both growing seasons and number of branches/plant in the first growing season. The positive effect of calcium on plant vegetative growth parameters might be due to the calcium function as a second messenger in the signal conduction between environmental factors and plant responses in terms of growth and development (Reddy, 2001).

Data in Table 2 also show that vegetative growth of sweet potato plants received $72 \mathrm{~kg} \mathrm{~K} \mathrm{~K}_{2} \mathrm{O} / \mathrm{fed}$. fertilizer was significantly improved compared with the control plants. It is also clear from the obtained data that increasing the rate of applied $\mathrm{K}_{2} \mathrm{O}$ from 48 to $72 \mathrm{~kg} / \mathrm{fed}$. was associated with significant simulative effects on plant growth, except for number of branches/plant in the first growing season, also there were no significant differences between applied $\mathrm{K}_{2} \mathrm{O}$ at 48 and the control on number of branches/plant in the first growing season. The application of $72 \mathrm{~kg} \mathrm{~K} \mathrm{~K}_{2} \mathrm{O} / \mathrm{fed}$. were superior, it is significantly increased vine length, number of branches, leaf area, canopy dry weight/plant and total chlorophyll content of leaves, compared with the control treatment, in both growing seasons. These increases may be due to potassium role in physiological processes inside the plant, photosynthesis; increasing enzyme activity ( $\mathrm{K}$ is required as Co-factor for different enzymes. It also helps to main electroneutrality in plant cells), improving synthesis of protein, carbohydrates and fats, translocation of sugars, enabling their ability to resist pests and diseases (Dkhil et al., 2011). Moreover, potassium control of ionic balance, regulation of plant stomata and water use, activation of plant enzymes to metabolize carbohydrates for the manufacture of amino acids and proteins, increases root growth (Marschner, 2013). The increase in leaves and shoots number due to mineral fertilization might be referred to the favorable effect of $\mathrm{N}, \mathrm{P}$ and $\mathrm{K}$ on the meristematic activity of the sweet potato plant tissues.

These results are in agreement with those of Mukhopadhyay et al., (1992), Chakrabarty et al. (1993), Prasad et al. (1997) and Al-Easily (2002) on sweet potatoes, who indicated that vegetative growth of sweet potato plants was increased as potassium levels increased. In addition, Abd El-Baky et al. (2010) reported that potassium fertilizer had positive effect on sweet potato plants. The highest values of vegetative growth characters; i.e., vine length, number of leaves and branches, fresh and dry weight of leaves and branches as well as total fresh weight and leaves area were recorded in plants received 150 $\mathrm{kg} \mathrm{k}_{2} \mathrm{O} / \mathrm{fed}$.

Data presented in Table 2 reveal that foliar spray of sweet potato with salicylic acid and ascorbic acid at $200 \mathrm{ppm}$ led to significant increases in vine length, number of branches, leaf area, canopy dry weight/plant and total chlorophyll contents of leaves 
as compared with the control, in both growing seasons. Also the highest values of vine length, leaf area, canopy dry weight/plant and total chlorophyll contents of leaves were obtained from foliar spray of sweet potato with ascorbic acid at $200 \mathrm{ppm}$ while the highest values of number of branches/plant were exhibited from foliar spray of sweet potato with salicylic acid at $200 \mathrm{ppm}$. There were significant differences between both antioxidant of all vegetative growth parameters mentioned above. The superiority effect of ascorbic acid may be due to its wide range of important functions as antioxidant defense, photoprotection, regulation of photosynthesis, its role in nutritional cycle's activity in higher plants, electron transport system and as a cofactor for a large number of key enzymes in plants (Blokhina et al., 2003). Also, the effectiveness of any given antioxidant in the plant depends on which free radical is involved, and where the target of damage is. Thus, while in one particular system an antioxidant may protect against free radicals, in other systems it could have no effect at all, or in certain circumstances, an antioxidant even act a "Prooxidant" that generates toxic oxygen species (Munne-Bosch, 2005). Similar results were reported by Arisha (2000) and Gad El-Hak et al. (2002) on potato, Bardisi (2004) and El-Morsy et al. (2010) on garlic and Orabi and Mekki (2008) on sugar beet, who pointed out that the use of ascorbic acid markedly increased shoot growth, fresh and dry weight of plants, compared with untreated plants. Similarly, WenYing et al. (2008) on sweet potato, found that pre-planting application of salicylic acid significantly increased certain vegetative plant characteristics such as foliage fresh and dry weight/plant and plant height compared with untreated plants.

Table 2. Vegetative growth parameters of sweet potato plants as affected by calcium, potassium and some antioxidants; i.e., salicylic acid and ascorbic acid, separately at different rates during 2011 and 2012 growing seasons.

\begin{tabular}{|c|c|c|c|c|c|c|c|c|c|c|}
\hline \multirow{3}{*}{ Treatments } & \multicolumn{10}{|c|}{ Parameters } \\
\hline & \multicolumn{2}{|c|}{$\begin{array}{l}\text { Vine length } \\
\quad(\mathrm{cm})\end{array}$} & \multicolumn{2}{|c|}{$\begin{array}{l}\text { Number of } \\
\text { branches/plant }\end{array}$} & \multicolumn{2}{|c|}{$\begin{array}{c}\text { Leaf area/ } \\
\text { plant } \\
\left(\mathrm{m}^{2}\right)\end{array}$} & \multicolumn{2}{|c|}{$\begin{array}{c}\text { Canopy dry } \\
\text { weight/Plant } \\
\text { (g) }\end{array}$} & \multicolumn{2}{|c|}{$\begin{array}{c}\text { Total } \\
\text { Chlorophyll } \\
(\mathrm{A}+\mathrm{B}) \\
(\mathrm{mg} / \mathrm{g} . \mathrm{FW}) \\
\end{array}$} \\
\hline & 2011 & 2012 & 2011 & 2012 & 2011 & 2012 & 2011 & 2012 & 2011 & 2012 \\
\hline \multicolumn{11}{|l|}{ Calcium } \\
\hline Control & $170.17 \mathrm{~b}$ & $168.50 \mathrm{~b}$ & $16.20 \mathrm{a}$ & $14.80 \mathrm{~b}$ & $0.71 \mathrm{c}$ & $0.68 \mathrm{c}$ & $241.50 \mathrm{~b}$ & $235.22 \mathrm{c}$ & $3.93 \mathrm{c}$ & $4.21 \mathrm{c}$ \\
\hline $1000 \mathrm{ppm}$ & $171.71 \mathrm{~b}$ & $170.43 \mathrm{~b}$ & $17.98 \mathrm{a}$ & $16.86 \mathrm{a}$ & $0.86 \mathrm{~b}$ & $0.84 \mathrm{~b}$ & $256.23 \mathrm{a}$ & $254.12 \mathrm{~b}$ & $4.25 \mathrm{~b}$ & $4.43 \mathrm{~b}$ \\
\hline $2000 \mathrm{ppm}$ & $176.36 \mathrm{a}$ & $172.94 \mathrm{a}$ & $18.79 \mathrm{a}$ & $18.00 \mathrm{a}$ & $0.90 \mathrm{a}$ & $0.88 \mathrm{a}$ & $257.75 \mathrm{a}$ & $255.96 \mathrm{a}$ & $4.43 \mathrm{a}$ & $4.59 \mathrm{a}$ \\
\hline \multicolumn{11}{|l|}{ Potassium } \\
\hline Control & $156.98 \mathrm{c}$ & $157.86 \mathrm{c}$ & $16.21 \mathrm{~b}$ & $14.39 \mathrm{c}$ & $0.69 \mathrm{c}$ & $0.65 \mathrm{c}$ & $219.05 \mathrm{c}$ & $210.19 \mathrm{c}$ & $3.73 \mathrm{c}$ & $3.94 \mathrm{c}$ \\
\hline $48 \mathrm{~kg} \mathrm{~K}_{2} \mathrm{O} / \mathrm{fed}$ & $173.62 \mathrm{~b}$ & $169.16 \mathrm{~b}$ & $17.91 \mathrm{ab}$ & $16.60 \mathrm{~b}$ & $0.81 \mathrm{~b}$ & $0.81 \mathrm{~b}$ & $257.40 \mathrm{~b}$ & $253.20 \mathrm{~b}$ & $4.22 \mathrm{~b}$ & $4.46 \mathrm{~b}$ \\
\hline $72 \mathrm{~kg} \mathrm{~K}_{2} \mathrm{O} / \mathrm{fed}$ & $187.65 \mathrm{a}$ & $184.84 \mathrm{a}$ & $18.84 \mathrm{a}$ & $18.67 \mathrm{a}$ & $0.97 \mathrm{a}$ & $0.95 \mathrm{a}$ & $279.04 \mathrm{a}$ & $281.92 \mathrm{a}$ & $4.65 \mathrm{a}$ & $4.82 \mathrm{a}$ \\
\hline \multicolumn{11}{|l|}{ Antioxidants } \\
\hline Control & $160.88 \mathrm{c}$ & $158.44 \mathrm{c}$ & $13.81 \mathrm{c}$ & $13.84 \mathrm{c}$ & $0.68 \mathrm{c}$ & $0.65 \mathrm{c}$ & $220.79 \mathrm{c}$ & $213.92 \mathrm{c}$ & $3.79 \mathrm{c}$ & $4.04 \mathrm{c}$ \\
\hline Salicylic acid & $175.67 \mathrm{~b}$ & $172.74 \mathrm{~b}$ & $20.63 \mathrm{a}$ & $18.76 \mathrm{a}$ & $0.83 \mathrm{~b}$ & $0.82 \mathrm{~b}$ & $247.35 \mathrm{~b}$ & $246.27 \mathrm{~b}$ & $4.27 \mathrm{~b}$ & $4.43 \mathrm{~b}$ \\
\hline Ascorbic acid & $181.69 \mathrm{a}$ & $180.69 \mathrm{a}$ & $18.52 \mathrm{~b}$ & $17.05 \mathrm{~b}$ & $0.95 \mathrm{a}$ & $0.94 \mathrm{a}$ & $287.33 \mathrm{a}$ & $285.11 \mathrm{a}$ & $4.54 \mathrm{a}$ & $4.75 \mathrm{a}$ \\
\hline
\end{tabular}

Means with the same letters are not significantly differed at $5 \%$ according to Duncan's multiple range test.

Salicylic acid and Ascorbic acid were applied at $200 \mathrm{ppm}$.

The effect of the interaction between calcium with potassium on plant vegetative growth parameters of sweet potato is presented in Table 3 . The interaction had a positive significant effect on vine length, number of branches, leaf area, canopy dry weight/plant and total chlorophyll content in plant leaves in both growing seasons. Results also indicated that plants treated with foliar spray of calcium at $1000 \mathrm{ppm}$ and $72 \mathrm{~kg} \mathrm{~K} \mathrm{~K}_{2} \mathrm{O} / \mathrm{fed}$. gave the highest values of vegetative growth parameters in both growing seasons, followed by calcium at 2000 ppm and $72 \mathrm{~kg} \mathrm{~K} \mathrm{~K}_{2} \mathrm{O} / \mathrm{fed}$. while the untreated plants (control) yielded the lowest values in both growing seasons, respectively. There were no significant differences between spray of calcium at 1000 and $2000 \mathrm{ppm}$ with $72 \mathrm{~kg} \mathrm{~K}_{2} \mathrm{O} / \mathrm{fed}$. on vine length, number of branches, leaf area/plant and total chlorophyll, in both seasons. There were no significant differences between sprayed of calcium at 1000 or $2000 \mathrm{ppm}$ with $72 \mathrm{~kg} \mathrm{~K} \mathrm{~K}_{2} \mathrm{O} / \mathrm{fed}$. and calcium at $0 \mathrm{ppm}$ (control) with $72 \mathrm{~kg} \mathrm{~K}_{2} \mathrm{O} /$ fed. on vine length, in both growing seasons and number of branches/plant in the second growing season. Also there were no significant differences between spray of calcium at 1000 ppm with 48 or $72 \mathrm{~kg} \mathrm{~K}_{2} \mathrm{O} /$ fed. and spray of calcium at 2000 ppm with 0 or 48 or 72 $\mathrm{kg} \mathrm{K}_{2} \mathrm{O} / \mathrm{fed}$. on number of branches/plant, in the first growing season and there were no significant differences between spray of calcium at $0 \mathrm{ppm}$ (control) or $1000 \mathrm{ppm}$ with $72 \mathrm{~kg} \mathrm{~K} \mathrm{~K}_{2} \mathrm{O} / \mathrm{fed}$. and spray of calcium at $2000 \mathrm{ppm}$ with 48 or $72 \mathrm{~kg}$ $\mathrm{K}_{2} \mathrm{O} /$ fed. on number of branches/plant, in the second 
growing season. Similar results were reported by Gashti et al. (2012) on peanut (Arachis hypogaea L.), they said that efficient application of fertilizers,

Table 3. Vegetative growth parameters of sweet potato plants as affected by the interactions between calcium and potassium at different rates during 2011 and 2012 growing seasons.

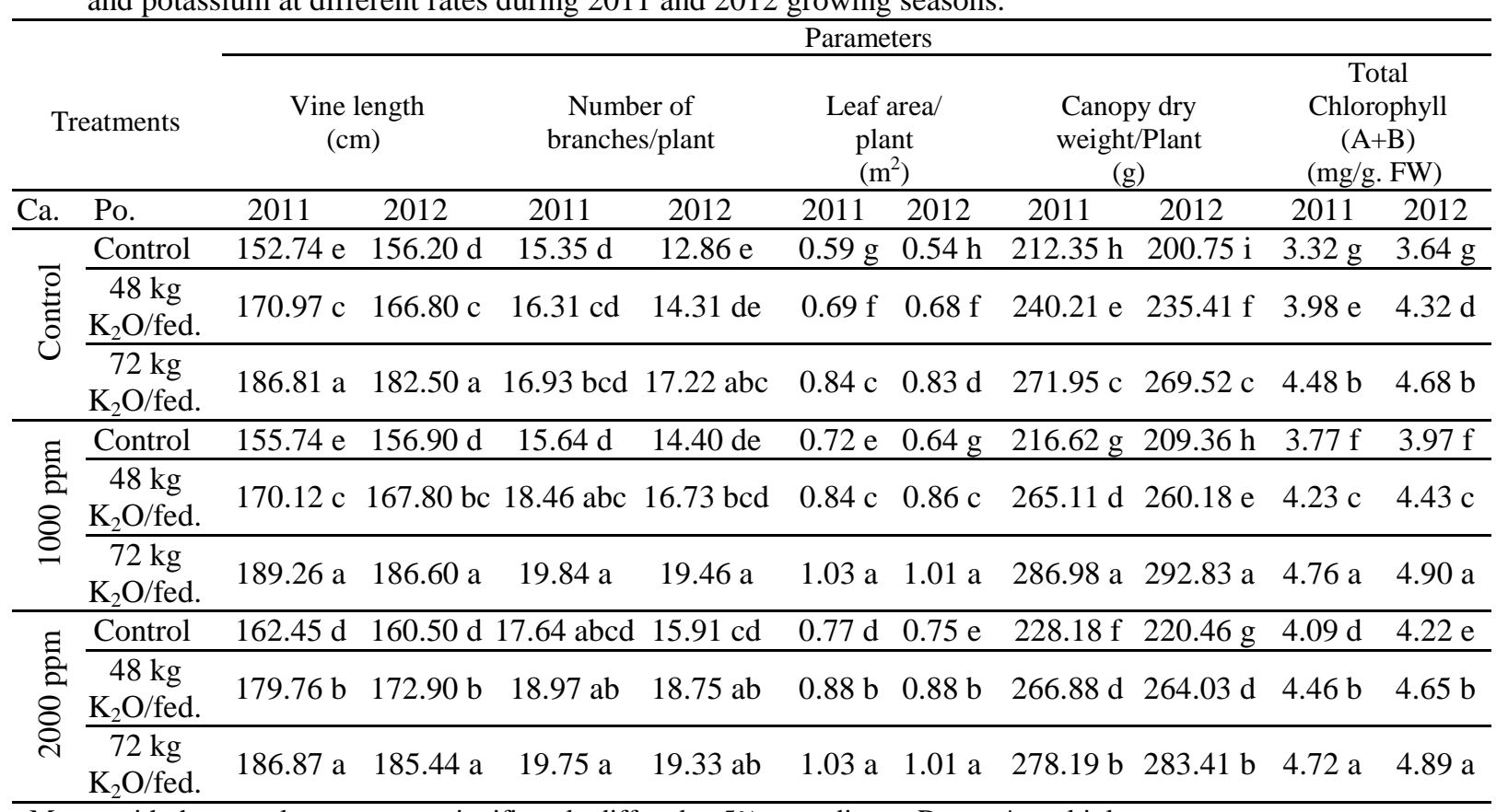

Means with the same letters are not significantly differed at 5\% according to Duncan's multiple range test. Ca. $=$ Calcium \& Po. = Potassium.

Regarding the interaction between calcium and antioxidants; i.e., salicylic acid or ascorbic acid, the data presented in Table 4, show obviously that a significant increase in vegetative growth of sweet potato plants, expressed as vine length, number of branches, leaf area, canopy dry weight/plant and total chlorophyll content in plant leaves, in both growing seasons. The interaction between calcium at 1000 ppm or $2000 \mathrm{ppm}$ and ascorbic acid at $200 \mathrm{ppm}$ resulted in the highest values of vegetative growth parameters compared with the control except for vine length, in the first growing season. There were no significant differences between sprayed of calcium at 0 ppm (control), $1000 \mathrm{ppm}$ and $2000 \mathrm{ppm}$ with ascorbic acid at $200 \mathrm{ppm}$ on vine length, in both seasons. Also there were no significant differences between sprayed of calcium at 2000 ppm with salicylic acid or ascorbic acid at $200 \mathrm{ppm}$ on vine length, in the first growing season. For number of branches/plant, there were no significant differences between spray of calcium at 1000 or 2000 ppm with salicylic acid or ascorbic acid at $200 \mathrm{ppm}$ and spray of calcium at $0 \mathrm{ppm}$ (control) with salicylic acid at $200 \mathrm{ppm}$, in both growing seasons while there were no significant differences between sprayed of calcium at 1000 or $2000 \mathrm{ppm}$ with ascorbic acid at $200 \mathrm{ppm}$ on canopy dry weight/plant, in the second growing seasons. Similar results were reported by El-Sherbini (2011) on tomato (Castle Rock cv.), who concluded that spray plants with boron at 50 $\mathrm{mg} / \mathrm{l}$, calcium at $2000 \mathrm{mg} / \mathrm{l}$, salicylic acid at $100 \mathrm{mg} / \mathrm{l}$ and selenium at concentration of $50 \mathrm{mg} / \mathrm{l}$ mixed with vitamin $\mathrm{E}$ at concentration of $150 \mathrm{mg} / \mathrm{l}$ as foliar application improve tomato vegetative growth under high temperature conditions in summer season.

The effects of the interactions among potassium and antioxidants namely salicylic acid or ascorbic acid on vegetative growth of sweet potato plants are recorded in Table 5. Results show that there is a positive effect for the interaction between potassium and antioxidants on all the studied vegetative growth characters of sweet potato plants in both growing seasons. The highest values of the studied vegetative growth characters were produced when $72 \mathrm{~kg}$ $\mathrm{K}_{2} \mathrm{O} /$ fed. interacted with ascorbic acid (200 ppm) and the lowest values were produced with the control, except number of branches/plant, where the highest values were produced when $72 \mathrm{~kg} \quad \mathrm{~K}_{2} \mathrm{O} / \mathrm{fed}$. interacted with salicylic acid at $200 \mathrm{ppm}$. There were no significant differences between applied potassium at $72 \mathrm{~kg} \mathrm{~K} 2 \mathrm{O} / \mathrm{fed}$. plus sprayed with salicylic acid or ascorbic acid at $200 \mathrm{ppm}$ on vine length, in the first growing season also there were no significant differences between applied potassium at $48 \mathrm{~kg}$ $\mathrm{K}_{2} \mathrm{O} /$ fed. plus spray with salicylic acid at $200 \mathrm{ppm}$ and applied potassium at $72 \mathrm{~kg} \mathrm{~K}_{2} \mathrm{O} /$ fed. plus spray with salicylic acid or ascorbic acid at $200 \mathrm{ppm}$ on number of branches/plant, in both growing seasons or applied potassium at $0 \mathrm{~kg} \mathrm{~K} 2 \mathrm{O} / \mathrm{fed}$. (control) plus spray with salicylic acid at $200 \mathrm{ppm}$, in the first growing season. The obtained results could be explained by the results of WuZhong et al. (1997) 
who found that $\mathrm{K}$ application improved the quality of the products by increasing vitamin $\mathrm{C}$ (ascorbic acid) levels in taro plants.

Table 4. Vegetative growth parameters of sweet potato plants as affected by the interactions between calcium and some antioxidants; i.e., salicylic acid and ascorbic acid, separately at different rates during 2011 and 2012 growing seasons.

\begin{tabular}{|c|c|c|c|c|c|c|c|c|c|c|}
\hline \multirow[b]{2}{*}{ Treatments } & \multicolumn{10}{|c|}{ Parameters } \\
\hline & \multicolumn{2}{|c|}{$\begin{array}{l}\text { Vine length } \\
\quad(\mathrm{cm})\end{array}$} & \multicolumn{2}{|c|}{$\begin{array}{c}\text { Number of } \\
\text { branches/plant }\end{array}$} & \multicolumn{2}{|c|}{$\begin{array}{c}\text { Leaf area/ } \\
\text { plant } \\
\left(\mathrm{m}^{2}\right)\end{array}$} & \multicolumn{2}{|c|}{$\begin{array}{l}\text { Canopy dry } \\
\text { weight/plant } \\
\text { (g) }\end{array}$} & \multicolumn{2}{|c|}{$\begin{array}{c}\text { Total } \\
\text { Chlorophyll } \\
(\mathrm{A}+\mathrm{B}) \\
(\mathrm{mg} / \mathrm{g} . \mathrm{FW})\end{array}$} \\
\hline An. & 2011 & 2012 & 2011 & 2012 & 2011 & 2012 & 2011 & 2012 & 2011 & 2012 \\
\hline Control & $155.34 \mathrm{e}$ & $154.40 \mathrm{e}$ & $13.08 \mathrm{c}$ & $11.80 \mathrm{~d}$ & $0.59 \mathrm{i}$ & $0.54 \mathrm{i}$ & $211.03 \mathrm{i}$ & $203.46 \mathrm{~g}$ & $3.52 \mathrm{~h}$ & $3.86 \mathrm{~g}$ \\
\hline $\overrightarrow{\text { Sa. acid }}$ & $172.45 \mathrm{~cd}$ & $170.90 \mathrm{c}$ & $19.48 \mathrm{a}$ & $17.77 \mathrm{ab}$ & $0.72 \mathrm{~g}$ & $0.69 \mathrm{~g}$ & $242.83 \mathrm{f}$ & $236.38 \mathrm{e}$ & $3.99 \mathrm{f}$ & $4.21 \mathrm{e}$ \\
\hline$\circlearrowright \circ$ As. acid & $182.73 \mathrm{a}$ & $180.20 \mathrm{ab}$ & $16.02 \mathrm{~b}$ & $14.82 \mathrm{c}$ & $0.81 \mathrm{e}$ & $0.83 \mathrm{e}$ & $270.64 \mathrm{c}$ & $265.83 \mathrm{~b}$ & $4.26 \mathrm{e}$ & $4.57 \mathrm{c}$ \\
\hline Control & $159.64 \mathrm{e}$ & $157.60 \mathrm{de}$ & $13.64 \mathrm{bc}$ & $14.11 \mathrm{~cd}$ & $0.69 \mathrm{~h}$ & $0.65 \mathrm{~h}$ & $224.43 \mathrm{~h}$ & $219.70 \mathrm{f}$ & $3.88 \mathrm{~g}$ & $4.02 \mathrm{f}$ \\
\hline $8 \equiv$ Sa. acid & $175.54 \mathrm{bc}$ & $172.66 \mathrm{c}$ & $21.04 \mathrm{a}$ & $19.00 \mathrm{a}$ & $0.87 \mathrm{~d}$ & $0.89 \mathrm{c}$ & $246.05 \mathrm{e}$ & $248.16 \mathrm{~d}$ & $4.33 \mathrm{~d}$ & $4.51 \mathrm{~d}$ \\
\hline$=$ As. acid & $179.94 \mathrm{ab}$ & $181.03 \mathrm{a}$ & $19.26 \mathrm{a}$ & $17.48 \mathrm{ab}$ & $1.03 \mathrm{a}$ & $0.98 \mathrm{~b}$ & $298.22 \mathrm{a}$ & $294.50 \mathrm{a}$ & $4.55 \mathrm{~b}$ & $4.76 \mathrm{~b}$ \\
\hline \multirow{3}{*}{ 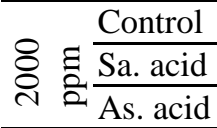 } & $167.66 \mathrm{~d}$ & $163.33 \mathrm{~d}$ & $14.71 \mathrm{bc}$ & $15.62 \mathrm{bc}$ & $0.77 \mathrm{f}$ & $0.76 \mathrm{f}$ & $226.92 \mathrm{~g}$ & $218.60 \mathrm{f}$ & $3.98 \mathrm{f}$ & $4.24 \mathrm{e}$ \\
\hline & $179.03 \mathrm{ab}$ & $174.65 \mathrm{bc}$ & $21.37 \mathrm{a}$ & $19.51 \mathrm{a}$ & $0.89 \mathrm{c}$ & $0.88 \mathrm{~d}$ & $253.17 \mathrm{~d}$ & $254.28 \mathrm{c}$ & $4.48 \mathrm{c}$ & $4.58 \mathrm{c}$ \\
\hline & $182.40 \mathrm{a}$ & $180.85 \mathrm{a}$ & $20.28 \mathrm{a}$ & $18.86 \mathrm{a}$ & $1.02 \mathrm{~b}$ & $1.01 \mathrm{a}$ & $293.14 \mathrm{~b}$ & $295.02 \mathrm{a}$ & $4.82 \mathrm{a}$ & $4.93 \mathrm{a}$ \\
\hline
\end{tabular}

Means with the same letters are not significantly differed at 5\% according to Duncan's multiple range test.

Ca. $=$ Calcium \& An.$=$ Antioxidants \& Sa. acid $=$ Salicylic Acid \& As. acid $=$ Ascorbic Acid.

Salicylic acid and Ascorbic acid were applied at $200 \mathrm{ppm}$.

Table 5. Vegetative growth parameters of sweet potato plants as affected by the interactions between potassium and some antioxidants; i.e., salicylic acid and ascorbic acid, separately at different rates during 2011 and 2012 growing seasons.

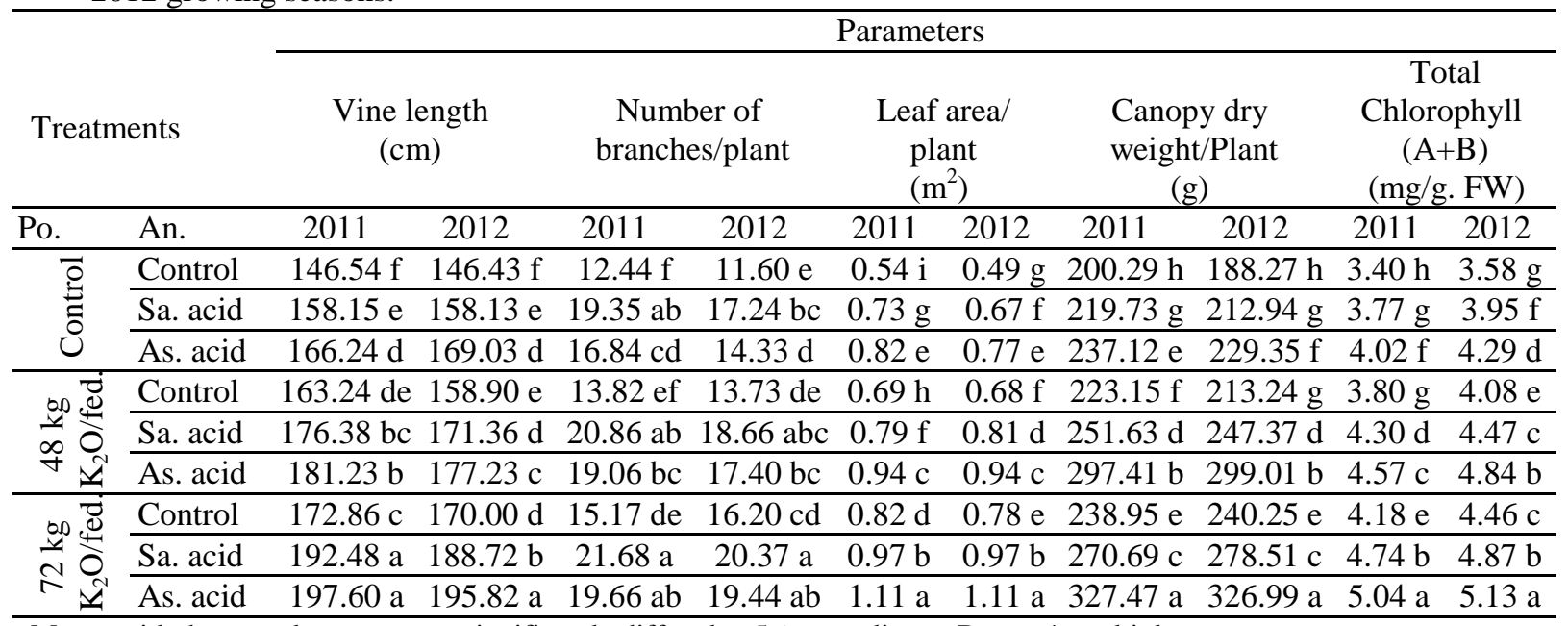

Means with the same letters are not significantly differed at $5 \%$ according to Duncan's multiple range test.

Po. $=$ Potassium \& An. $=$ Antioxidants $\&$ Sa. acid $=$ Salicylic Acid $\&$ As. acid $=$ Ascorbic Acid.

Salicylic acid and Ascorbic acid were applied at $200 \mathrm{ppm}$.

As for the interaction effect among the three studied factors, data in Table 6 reveal that vine length, number of branches, leaf area, canopy dry weight/plant and total chlorophyll content were significantly influenced by the interaction, in both growing seasons. Generally, plants treated with foliar spray of calcium at $1000 \mathrm{ppm}$, fertilized with $72 \mathrm{~kg}$ $\mathrm{K}_{2} \mathrm{O} /$ fed. and sprayed with ascorbic acid at $200 \mathrm{ppm}$ resulted in the highest values of studied vegetative growth characters except for number of branches/plant, in both growing seasons and there are no significant differences between sprayed of calcium at 0 (control), 1000 and 2000 ppm with 72 $\mathrm{kg} \mathrm{K}_{2} \mathrm{O} / \mathrm{fed}$. plus sprayed with salicylic acid or ascorbic acid at $200 \mathrm{ppm}$ on vine length, in both growing seasons of study. For number of branches/plant, there were no significant differences between spray of calcium at 0 ppm (control) with 48 or $72 \mathrm{~kg} \mathrm{~K} \mathrm{~K}_{2} \mathrm{O} / \mathrm{fed}$. plus sprayed with salicylic acid at $200 \mathrm{ppm}$, sprayed of calcium at $1000 \mathrm{ppm}$ with 0 (control) or 48 or $72 \mathrm{~kg} \mathrm{~K}_{2} \mathrm{O} / \mathrm{fed}$. plus sprayed with salicylic acid at $200 \mathrm{ppm}$ and sprayed of calcium at 2000 ppm with 0 or 48 or $72 \mathrm{~kg} \mathrm{~K} 2 \mathrm{O} / \mathrm{fed}$. (control) plus spray with salicylic acid at $200 \mathrm{ppm}$, in both 
growing seasons, there are no significant differences between sprayed of calcium at 1000 ppm with 48 or $72 \mathrm{~kg} \mathrm{~K} \mathrm{~K}_{2} \mathrm{O} /$ fed. plus sprayed with salicylic acid or ascorbic acid at $200 \mathrm{ppm}$ and sprayed of calcium at 2000 ppm with 0 (control) or 48 or $72 \mathrm{~kg} \mathrm{~K}_{2} \mathrm{O} / \mathrm{fed}$.

Table 6. Vegetative growth parameters of sweet potato plants as affected by the interactions among calcium, potassium and some antioxidants; i.e., salicylic acid and ascorbic acid, separately at different rates during 2011 and 2012 growing seasons.

\begin{tabular}{|c|c|c|c|c|c|c|c|c|c|c|c|}
\hline \multirow{2}{*}{\multicolumn{3}{|c|}{ Treatments }} & \multicolumn{9}{|c|}{ Parameters } \\
\hline & & & \multicolumn{2}{|c|}{$\begin{array}{l}\text { Vine length } \\
\quad(\mathrm{cm})\end{array}$} & \multicolumn{2}{|c|}{$\begin{array}{l}\text { Number of } \\
\text { branches/plant }\end{array}$} & \multicolumn{2}{|c|}{$\begin{array}{c}\text { Leaf area/ } \\
\text { plant } \\
\left(\mathrm{m}^{2}\right) \\
\end{array}$} & $\begin{array}{c}\text { Canopy dry } \\
\text { weight/Plant } \\
(\mathrm{g})\end{array}$ & \multicolumn{2}{|c|}{$\begin{array}{c}\text { Total Chlorophyll } \\
\text { (A+B) } \\
(\mathrm{mg} / \mathrm{g} . \mathrm{FW})\end{array}$} \\
\hline $\mathrm{Ca}$. & Po. & An. & 2011 & 2012 & 2011 & 2012 & 2011 & 2012 & 2012 & 2011 & 2012 \\
\hline \multirow{9}{*}{ 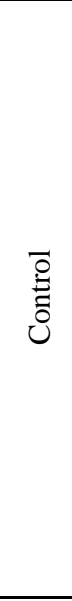 } & \multirow{3}{*}{ 宊 } & Control & $139.80 \mathrm{p}$ & $145.80 \mathrm{j}$ & $12.26 \mathrm{i}$ & $9.93 \mathrm{~h}$ & $0.43 \mathrm{~s}$ & $0.37 \mathrm{u}$ & $189.27 \mathrm{~s} \quad 180.35 \mathrm{t}$ & $3.05 n$ & $3.28 \mathrm{p}$ \\
\hline & & Sa. acid & 150.30 no & 152.40 hij & $\begin{array}{l}18.60 \\
\text { bcdefg }\end{array}$ & $\begin{array}{l}16.26 \\
\text { bcdefg }\end{array}$ & $0.64 \mathrm{p}$ & $0.60 \mathrm{~s}$ & 211.14 pq 200.82 q & $3.34 \mathrm{~m}$ & $3.63 \mathrm{o}$ \\
\hline & & As. acid & $\begin{array}{l}168.13 \\
\text { hijk }\end{array}$ & $\begin{array}{c}170.40 \\
\text { cdef }\end{array}$ & 15.20 fghi & $12.40 \mathrm{fgh}$ & $0.71 \mathrm{n}$ & $0.66 \mathrm{p}$ & $236.64 \mathrm{kl} 221.08 \mathrm{n}$ & $3.58 \mathrm{k}$ & $4.01 \mathrm{~lm}$ \\
\hline & \multirow{3}{*}{ 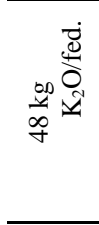 } & Control & $\begin{array}{l}155.50 \\
\mathrm{mn}\end{array}$ & 151.90 hij & $13.06 \mathrm{hi}$ & $11.26 \mathrm{~h}$ & $0.61 \mathrm{q}$ & $0.59 \mathrm{~s}$ & 209.64 q 201.56 q & $3.54 \mathrm{kl}$ & $3.97 \mathrm{~m}$ \\
\hline & & Sa. acid & $\begin{array}{l}175.20 \\
\text { efgh }\end{array}$ & $\begin{array}{c}173.00 \\
\text { cde }\end{array}$ & 19.60 abcde & $\begin{array}{l}17.33 \\
\text { abcde }\end{array}$ & 0.68 o & $0.61 \mathrm{r}$ & 239.89 k 238.421 & $4.12 \mathrm{f}$ & $4.26 \mathrm{hi}$ \\
\hline & & As. acid & $\begin{array}{l}182.23 \\
\text { cde }\end{array}$ & $\begin{array}{l}175.50 \\
\text { cde }\end{array}$ & $\begin{array}{l}16.26 \\
\text { defghi }\end{array}$ & $\begin{array}{c}14.33 \\
\text { cdefgh }\end{array}$ & $0.79 \mathrm{k}$ & $0.83 \mathrm{k}$ & 271.09 f $266.25 \mathrm{i}$ & $4.27 \mathrm{e}$ & $4.73 \mathrm{de}$ \\
\hline & \multirow{3}{*}{ 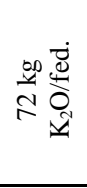 } & Control & $\begin{array}{l}170.73 \\
\text { ghij }\end{array}$ & 165.50 efg & $13.93 \mathrm{hi}$ & $\begin{array}{l}14.20 \\
\text { cdefgh }\end{array}$ & $0.85 \mathrm{i}$ & $0.65 \mathrm{q}$ & $234.18 \operatorname{lm} 228.48 \mathrm{~m}$ & $3.97 \mathrm{gh}$ & $4.35 \mathrm{~h}$ \\
\hline & & Sa. acid & $191.86 \mathrm{ab}$ & $187.30 \mathrm{ab} 2$ & 20.26 abcde & $19.73 \mathrm{ab}$ & $0.73 \mathrm{~m}$ & $0.86 \mathrm{~h}$ & 277.47 e $269.92 \mathrm{~h}$ & $4.52 \mathrm{~d}$ & $4.73 \mathrm{de}$ \\
\hline & & As. acid & $197.83 \mathrm{a}$ & $194.70 \mathrm{a}$ & $\begin{array}{l}16.60 \\
\text { cdefgh }\end{array}$ & $17.73 \mathrm{abcd}$ & $0.94 \mathrm{f}$ & $0.99 \mathrm{~d}$ & 304.19 d $310.16 \mathrm{e}$ & $4.94 \mathrm{~b}$ & $4.98 \mathrm{c}$ \\
\hline \multirow{9}{*}{ 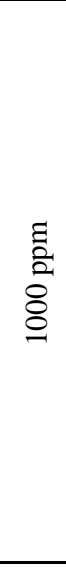 } & \multirow{3}{*}{ 㟃 } & Control & 144.46 op & $142.80 \mathrm{j}$ & $12.20 \mathrm{i}$ & $11.93 \mathrm{gh}$ & $0.50 \mathrm{r}$ & $0.44 \mathrm{t}$ & $197.42 \mathrm{r} 190.21 \mathrm{~s}$ & $3.45 \mathrm{~lm}$ & $3.62 \mathrm{o}$ \\
\hline & & Sa. acid & $\begin{array}{l}159.03 \\
\operatorname{lmn}\end{array}$ & $\begin{array}{l}161.10 \\
\text { fgh }\end{array}$ & $\begin{array}{c}18.73 \\
\text { abcdefg }\end{array}$ & $\begin{array}{l}17.33 \\
\text { abcde }\end{array}$ & 0.761 & $0.70 \mathrm{o}$ & 215.18 o 209.85 p & $3.80 \mathrm{ij}$ & $4.08 \mathrm{kl}$ \\
\hline & & As. acid 1 & $163.73 \mathrm{jklm}$ & 166.80 efg 1 & 16.00 efghi & $\begin{array}{l}13.93 \\
\text { defgh }\end{array}$ & $0.88 \mathrm{~g}$ & 0.791 & $237.25 \mathrm{kl} 228.02 \mathrm{~m}$ & $4.05 \mathrm{fg}$ & $4.22 \mathrm{ij}$ \\
\hline & & Control & $\begin{array}{l}160.06 \\
\mathrm{klm}\end{array}$ & 157.70 ghi & 13.46 hi & $\begin{array}{l}13.66 \\
\text { defgh }\end{array}$ & $0.71 \mathrm{n}$ & $0.66 \mathrm{pq}$ & 229.73 n 216.96 о & $3.91 \mathrm{hi}$ & $4.00 \mathrm{~lm}$ \\
\hline & & Sa. acid & $\begin{array}{l}173.13 \\
\text { fghi }\end{array}$ & 166.60 efg & $21.40 \mathrm{ab}$ & $8.60 \mathrm{abc}$ & $0.82 \mathrm{j}$ & $0.94 \mathrm{e}$ & 254.12 i $249.77 \mathrm{k}$ & $4.27 \mathrm{e}$ & $4.48 \mathrm{~g}$ \\
\hline & & As. acid & $\begin{array}{l}177.16 \\
\text { defg }\end{array}$ & $179.10 \mathrm{bc}$ & $20.53 \mathrm{abcd}$ & $17.93 \mathrm{abcd}$ & $1.00 \mathrm{e}$ & $0.99 \mathrm{~d}$ & 311.48 c 313.82 d & $4.52 \mathrm{~d}$ & $4.80 \mathrm{~d}$ \\
\hline & \multirow{3}{*}{ 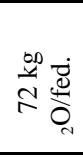 } & Control & $\begin{array}{l}174.40 \\
\text { efgh }\end{array}$ & $\begin{array}{l}172.30 \\
\text { cde }\end{array}$ & 15.26 fghi & $\begin{array}{c}16.73 \\
\text { abcdef }\end{array}$ & $0.86 \mathrm{hi}$ & $0.84 \mathrm{j}$ & $246.15 \mathrm{j} 251.95 \mathrm{jk}$ & $4.27 \mathrm{e}$ & $4.45 \mathrm{~g}$ \\
\hline & & Sa. acid & $194.46 \mathrm{a}$ & $190.30 \mathrm{a}$ & $23.00 \mathrm{a}$ & $21.06 \mathrm{a}$ & $1.04 \mathrm{c}$ & $1.03 \mathrm{c}$ & $268.85 \mathrm{fg} 284.88 \mathrm{f}$ & $4.93 \mathrm{~b}$ & $4.97 \mathrm{c}$ \\
\hline & & As. acid & $198.93 \mathrm{a}$ & $197.20 \mathrm{a}$ & $21.26 \mathrm{ab}$ & $20.60 \mathrm{ab}$ & $1.20 \mathrm{a}$ & $1.17 \mathrm{a}$ & 345.94 a $341.66 \mathrm{a}$ & $5.09 \mathrm{a}$ & $5.27 \mathrm{a}$ \\
\hline \multirow{9}{*}{ 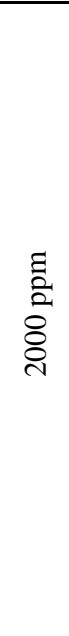 } & \multirow{3}{*}{ 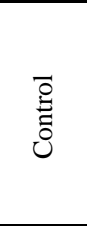 } & Control & $\begin{array}{l}155.36 \\
\mathrm{mn}\end{array}$ & $150.70 \mathrm{ij}$ & $12.86 \mathrm{hi}$ & $12.93 \mathrm{efgh}$ & $0.79 \mathrm{k}$ & $0.66 \mathrm{p}$ & 214.18 op 194.26 r & $3.69 \mathrm{j}$ & $3.86 \mathrm{n}$ \\
\hline & & Sa. acid & $\begin{array}{l}165.13 \\
\mathrm{ijkl}\end{array}$ & $\begin{array}{l}160.90 \\
\text { fgh }\end{array}$ & $20.73 \mathrm{abc}$ & $18.13 \mathrm{abcd}$ & $0.86 \mathrm{hi}$ & $0.72 \mathrm{n}$ & $\begin{array}{cc}\begin{array}{c}232.88 \\
\mathrm{mn}\end{array} & 228.17 \mathrm{~m} \\
\end{array}$ & $4.15 \mathrm{f}$ & $4.15 \mathrm{jk}$ \\
\hline & & As. acid 1 & 166.86 hijk] & $\begin{array}{c}169.90 \\
\text { cdef }\end{array}$ & $\begin{array}{c}19.33 \\
\text { abcdef }\end{array}$ & $\begin{array}{c}16.66 \\
\text { abcdef }\end{array}$ & 0.761 & $0.87 \mathrm{~g}$ & $237.48 \mathrm{kl} 238.951$ & $4.44 \mathrm{~d}$ & 4.64 ef \\
\hline & \multirow{3}{*}{ 임 } & Control & $\begin{array}{l}174.16 \\
\text { efgh }\end{array}$ & $\begin{array}{c}167.10 \\
\text { defg }\end{array}$ & 14.93 ghi & $\begin{array}{r}16.26 \\
\text { bcdefg }\end{array}$ & $0.86 \mathrm{~h}$ & $0.77 \mathrm{~m}$ & 230.08 n 221.21 n & $3.96 \mathrm{gh}$ & $4.27 \mathrm{hi}$ \\
\hline & & Sa. acid & $\begin{array}{l}180.83 \\
\text { def }\end{array}$ & $\begin{array}{l}174.50 \\
\text { cde }\end{array}$ & $21.60 \mathrm{ab}$ & $20.06 \mathrm{ab}$ & $1.03 \mathrm{~d}$ & $0.88 \mathrm{f}$ & $260.88 \mathrm{~h} 253.92 \mathrm{j}$ & $4.50 \mathrm{~d}$ & 4.68 ef \\
\hline & & As. acid & $\begin{array}{l}184.30 \\
\text { bcd }\end{array}$ & $177.10 \mathrm{~cd} 2$ & $20.40 \mathrm{abcd}$ & $19.93 \mathrm{ab}$ & $0.88 \mathrm{~g}$ & $0.99 \mathrm{~d}$ & 309.68 c 316.96 c & $4.92 \mathrm{~b}$ & $5.00 \mathrm{c}$ \\
\hline & \multirow{3}{*}{ 竞总 } & Control & $\begin{array}{l}173.46 \\
\text { efghi }\end{array}$ & $\begin{array}{c}172.20 \\
\text { cde }\end{array}$ & $\begin{array}{c}16.33 \\
\text { defghi }\end{array}$ & $17.66 \mathrm{abcd}$ & $1.03 \mathrm{~cd}$ & $0.85 \mathrm{i}$ & $236.51 \mathrm{kl} 240.341$ & $4.29 \mathrm{e}$ & $4.60 \mathrm{f}$ \\
\hline & & Sa. acid & $\begin{array}{l}191.13 \\
\mathrm{abc}\end{array}$ & $188.56 \mathrm{ab}$ & $21.80 \mathrm{ab}$ & $20.33 \mathrm{ab}$ & $1.18 \mathrm{~b}$ & $1.03 \mathrm{c}$ & $265.77 \mathrm{~g} 280.75 \mathrm{~g}$ & $4.78 \mathrm{c}$ & $4.92 \mathrm{c}$ \\
\hline & & As. acid & $196.03 \mathrm{a}$ & $195.56 \mathrm{a}$ & $21.13 \mathrm{ab}$ & $20.00 \mathrm{ab}$ & $0.79 \mathrm{k}$ & $1.16 \mathrm{~b}$ & 332.28 b 329.15 b & $5.09 \mathrm{a}$ & $5.16 \mathrm{~b}$ \\
\hline
\end{tabular}

Means with the same letters are not significantly differed at 5\% according to Duncan's multiple range test.

Ca. $=$ Calcium \& Po. $=$ Potassium \& An. $=$ Antioxidants \& Sa. acid $=$ Salicylic Acid \& As. acid $=$ Ascorbic Acid

Salicylic acid and Ascorbic acid were applied at $200 \mathrm{ppm}$. 
plus spray with salicylic acid or ascorbic acid at 200 ppm, in both growing seasons, also there are no significant differences between spray of calcium at 0 (control) ppm with $72 \mathrm{~kg} \mathrm{~K}_{2} \mathrm{O} /$ fed. plus spray with ascorbic acid at $200 \mathrm{ppm}$, spray of calcium at 1000 ppm with $72 \mathrm{~kg} \mathrm{~K} \mathrm{O} /$ fed. and without antioxidants (control) and spray of calcium at 2000 ppm with 72 $\mathrm{kg} \mathrm{K}_{2} \mathrm{O} /$ fed. and without antioxidants (control), in the second growing season. For total chlorophyll, there were no significant differences between spray of calcium at 1000 or 2000 ppm with $72 \mathrm{~kg} \mathrm{~K}$ O/fed. plus spray with ascorbic acid at $200 \mathrm{ppm}$, in the first growing season.

\section{2- Yield and its components:}

Concerning the effect of calcium on yield and its components, data presented in Table 7 indicate that application of calcium at $2000 \mathrm{ppm}$ as foliar spray was generally more effective than the control on yield characters, where it exerted significant increases in total yield by $0.93 \%$, $0.86 \%$ and marketable yield by $1.29 \%, 1.26 \%$ in the first and second growing seasons, respectively. Calcium, also significantly increased total yield/plant, in both growing season, and significantly reduced non-marketable yield by $0.36 \%, 0.40 \%$ in the first and second growing seasons, respectively, while number of tubers roots/plant was not significantly influenced by calcium rates in both growing seasons. The superior effects of the used rate of $2000 \mathrm{ppm} \mathrm{Ca}$ in enhancing the aforesaid yield characters occurs herein may be due to its physiological effects on sweet potato plants which was found and discussed in the previous parts of plant vegetative growth, which positively affected root tuber yield. Moreover, the improving effect of calcium on yield and its components might be du to that calcium is component of the middle lamella and is essential for intracellular membrane transport. Likewise, calcium is known to act as a signaling molecule that can regulate metabolism, controlling respiration, reducing ethylene production in plant (Marschner, 2013).

This is in coincidence with the findings of Clough (1994) who found that potato yield, size distribution, specific gravity and grade were significantly affected by $\mathrm{Ca}$ treatments, also Sulaiman et al. (2004) found that tuberous roots in sweet potato varieties at 90 and 120 day after plants were lighter at the high $\mathrm{Ca}$ of $28 \mathrm{mg} \mathrm{Ca} / \mathrm{L}$ than the control of $10 \mathrm{mg} \mathrm{Ca} / \mathrm{L}$.

Data in Table 7 also show the effect of potassium on yield and its components of sweet potato. Irrespective of the unfertilized plants, increasing the supplied potassium from 48 to $72 \mathrm{~kg} \mathrm{~K}_{2} \mathrm{O} / \mathrm{fed}$. significantly increased total yield by $1.36 \%$ and 1.82
$\%$, marketable yield/fed, tuber yield/plant and number of tuber roots/plant in both growing seasons. Non-marketable yield significantly reduced, in both growing seasons, by increasing potassium from 48 to $72 \mathrm{~kg} \mathrm{~K} \mathrm{~K}_{2} \mathrm{O} / \mathrm{fed}$. and there were no significant differences between applied $\mathrm{K}_{2} \mathrm{O}$ at 48 and 72 $\mathrm{kg} / \mathrm{fed}$., also between applied $\mathrm{K}_{2} \mathrm{O}$ at 0 (control) and $48 \mathrm{~kg} / \mathrm{fed}$. on number of tuber/plant in the second growing season. These increases may be due to that potassium has an established reputation as a major controlling effect on tuber production in plant and it is the most important nutrient element needed by sweet potato in terms of nutrient uptake per unit area per unit tuber production. Since sweet potato is generally grown on highly weathered and leached soils where available $\mathrm{K}$ status is low, management of $\mathrm{K}$ assumes greatest significance (Byju and George, 2005). Also, the yield increase as a result of $K$ application was mainly due to the increase in root:top ratio which led to greater amount of photosynthate translocation to the storage roots causing their increase in size (George et al., 2002). Moreover, the increase in total yield of sweet potato resulting from $\mathrm{K}$ fertilization might be attributed to its favorable effect on the vegetative growth, nutrient content, and DM accumulation throughout plant tissues, also this might be related to the favorable effects of $\mathrm{K}$ on photosynthetic pigments, that possibly increased the efficiency of photosynthesis and resulted in more accumulation of stored food in the tubers.

Similar results were reported by Gowda et $\boldsymbol{a l}$. (1990) who found that the application of $120 \mathrm{~kg}$ $\mathrm{K}_{2} \mathrm{O} /$ ha. in 2 equal splits at basal and 30 days after planting produced a high yield of sweet potato, also Mukhopadhyay and Jana (1990) found that applying $75 \quad \mathrm{~K}_{2} \mathrm{O} /$ ha.to sweet potato as a basal dressing gave tuber yields of $16.0 \mathrm{t} / \mathrm{ha}$. compared with 10.3 t/ha. without $\mathrm{K}$, Mukhopadhyay et al. (1992) reported for sweet potato that number of tubers/plant (4.87) and tuber yield (18.16 t/ha.) were obtained from split application of $75 \mathrm{~kg} \mathrm{~K}_{2} \mathrm{O} / \mathrm{ha}$. and JianWei et al. (2001) indicated that sweet potato yield and quality respond strongly to $\mathrm{K}$ applications.

As for the effect of antioxidants on yield and its components of sweet potato, data presented in Table 7 reveal that all studied characters of sweet potato yield and its components, except the non-marketable yield, were generally greater with antioxidants treatments than the control. Sweet potato plants sprayed with ascorbic acid at $200 \mathrm{ppm}$, exerted significant increases over those sprayed with salicylic acid in the total yield, marketable yield and tuber yield/plant in both growing seasons, however, the differences in number of tuber roots/plant did not reach the level of significance in both growing seasons. Non-marketable yield significantly reduced by antioxidants treatments, in both growing seasons. The highest total yield was obtained from plants 
sprayed with ascorbic acid at 200 ppm. Plants sprayed with ascorbic acid at $200 \mathrm{ppm}$ increased total yield by $1.75 \%$ and $1.94 \%$ compared with the untreated ones, in the first and second growing seasons, respectively. In additions, a non-marketable yield was reduced by ascorbic acid treatment than without antioxidants by $0.42 \%$ and $0.36 \%$ in both growing seasons. The superior effects of the used rate of $200 \mathrm{ppm}$ ascorbic acid in enhancing the aforesaid yield characters occurs herein may be due to its physiological effects on sweet potato plants which was found and discussed in the previous parts of plant vegetative growth, which positively affected root tuber yield. Moreover, the favorable effect of ascorbic acid on yield and its components of sweet potato may be due to that ascorbic acid (Vit. C) has a wide range of important functions as antioxidant defense, photoprotection, regulation of photosynthesis, affects nutritional cycle's activity in higher plants, electron transport system, as a cofactor for a large number of key enzymes in plants, also developmental senescence, programmed cell death and responses to pathogens (Blokhina et al., 2003).

Also, these results may be attributed to the role of citric acid; it is one of a series of compounds involved in the physiological oxidation of fats, proteins and carbohydrates to $\mathrm{CO}_{2}$ and water as well as chelation of transition metals, e.g., citric acid. This kind of mode of action depends on the availability of metals in catalyzing amounts. Interference with this process of catalysis by chelation would be expected to have a strong effect on the progress of the radical reaction transition metal ions may either be activated by the chelator increasing the catalyzing potential or may be rendered inactive. The change brought depends on the metal and chelator (Abd Allah et al., 2007).

Table 7. Yield and its components of sweet potato plants as affected by calcium, potassium and some antioxidants; i.e., salicylic acid and ascorbic acid, separately at different rates during 2011 and 2012 growing seasons.

\begin{tabular}{|c|c|c|c|c|c|c|c|c|c|c|}
\hline \multirow{4}{*}{ Treatments } & \multicolumn{10}{|c|}{ Characters } \\
\hline & \multicolumn{4}{|c|}{ Yield/plant } & \multicolumn{6}{|c|}{ Yield/fed. } \\
\hline & \multicolumn{2}{|c|}{$\begin{array}{l}\text { Weight } \\
\text { (g) }\end{array}$} & \multicolumn{2}{|c|}{$\begin{array}{l}\text { Number of } \\
\text { tubers/plant }\end{array}$} & \multicolumn{2}{|c|}{$\begin{array}{c}\text { Marketable } \\
\text { yield } \\
\text { (ton/fed.) }\end{array}$} & \multicolumn{2}{|c|}{$\begin{array}{c}\text { Non- } \\
\text { marketable } \\
\text { yield } \\
\text { (ton/fed.) }\end{array}$} & \multicolumn{2}{|c|}{$\begin{array}{c}\text { Total yield } \\
\text { (ton/fed.) }\end{array}$} \\
\hline & 2011 & 2012 & 2011 & 2012 & 2011 & 2012 & 2011 & 2012 & 2011 & 2012 \\
\hline \multicolumn{11}{|l|}{ Calcium } \\
\hline Control & $888.60 \mathrm{c}$ & $900.90 \mathrm{c}$ & $3.84 \mathrm{a}$ & $4.10 \mathrm{a}$ & $12.74 \mathrm{c}$ & $11.96 \mathrm{c}$ & $1.32 \mathrm{a}$ & $1.50 \mathrm{a}$ & $14.07 \mathrm{c}$ & $13.46 \mathrm{c}$ \\
\hline $1000 \mathrm{ppm}$ & $918.20 \mathrm{~b}$ & $928.40 \mathrm{~b}$ & $4.02 \mathrm{a}$ & $4.32 \mathrm{a}$ & $13.68 \mathrm{~b}$ & $12.77 \mathrm{~b}$ & $1.06 \mathrm{~b}$ & $1.22 \mathrm{~b}$ & $14.74 \mathrm{~b}$ & $13.99 \mathrm{~b}$ \\
\hline $2000 \mathrm{ppm}$ & $930.77 \mathrm{a}$ & $940.60 \mathrm{a}$ & $4.21 \mathrm{a}$ & $4.44 \mathrm{a}$ & $14.03 \mathrm{a}$ & $13.22 \mathrm{a}$ & $0.96 \mathrm{c}$ & $1.10 \mathrm{c}$ & $15.00 \mathrm{a}$ & $14.32 \mathrm{a}$ \\
\hline \multicolumn{11}{|l|}{ Potassium } \\
\hline Control & $789.36 \mathrm{c}$ & $872.27 \mathrm{c}$ & $3.68 \mathrm{c}$ & $3.84 \mathrm{~b}$ & $12.53 \mathrm{c}$ & $11.57 \mathrm{c}$ & $1.29 \mathrm{a}$ & $1.47 \mathrm{a}$ & $13.83 \mathrm{c}$ & $13.05 \mathrm{c}$ \\
\hline $48 \mathrm{~kg} \mathrm{~K}_{2} \mathrm{O} / \mathrm{fed}$ & $913.31 \mathrm{~b}$ & $932.27 \mathrm{~b}$ & $4.03 \mathrm{~b}$ & $4.28 \mathrm{ab}$ & $13.66 \mathrm{~b}$ & $12.59 \mathrm{~b}$ & $1.12 \mathrm{~b}$ & $1.26 \mathrm{~b}$ & $14.78 \mathrm{~b}$ & $13.86 \mathrm{~b}$ \\
\hline $72 \mathrm{~kg} \mathrm{~K}_{2} \mathrm{O} / \mathrm{fed}$. & $1034.89 \mathrm{a}$ & $965.35 \mathrm{a}$ & $4.35 \mathrm{a}$ & $4.74 \mathrm{a}$ & $14.26 \mathrm{a}$ & $13.78 \mathrm{a}$ & $0.92 \mathrm{c}$ & $1.08 \mathrm{c}$ & $15.19 \mathrm{a}$ & $14.87 \mathrm{a}$ \\
\hline \multicolumn{11}{|l|}{ Antioxidants } \\
\hline Control & $753.06 \mathrm{c}$ & $779.79 \mathrm{c}$ & $3.56 \mathrm{~b}$ & $3.71 \mathrm{~b}$ & $12.37 \mathrm{c}$ & $11.37 \mathrm{c}$ & $1.35 \mathrm{a}$ & $1.45 \mathrm{a}$ & $13.72 \mathrm{c}$ & $12.83 \mathrm{c}$ \\
\hline Salicylic acid & $965.18 \mathrm{~b}$ & $970.89 \mathrm{~b}$ & $4.37 \mathrm{a}$ & $4.69 \mathrm{a}$ & $13.56 \mathrm{~b}$ & $12.90 \mathrm{~b}$ & $1.05 \mathrm{~b}$ & $1.27 \mathrm{~b}$ & $14.61 \mathrm{~b}$ & $14.17 \mathrm{~b}$ \\
\hline Ascorbic acid & $1019.32 \mathrm{a}$ & $1019.21 \mathrm{a}$ & $4.14 \mathrm{a}$ & $4.45 \mathrm{a}$ & $14.53 \mathrm{a}$ & $13.67 \mathrm{a}$ & $0.93 \mathrm{c}$ & $1.09 \mathrm{c}$ & $15.47 \mathrm{a}$ & $14.77 \mathrm{a}$ \\
\hline
\end{tabular}

Means with the same letters are not significantly differed at 5\% according to Duncan's multiple range test.

Salicylic acid and Ascorbic acid were applied at $200 \mathrm{ppm}$.

Regarding the interaction effect of calcium with potassium on sweet potato yield and its components, data in Table 8 show that there were significant effects, in both growing seasons, on total and marketable yield as well as tuber roots weight/plant and number of tuber roots/plant. Non-marketable yield significantly reduced, in both growing seasons, as a result of the interaction of the applied calcium with potassium, generally, most studied characters of yield and its components had the highest values as a result of the interaction of $72 \mathrm{~kg} \mathrm{~K}_{2} \mathrm{O} / \mathrm{fed}$. with foliar spray with calcium at $1000 \mathrm{ppm}$ and there were no significance differences between $72 \mathrm{~kg} \mathrm{~K}_{2} \mathrm{O} /$ fed. plus foliar spray with calcium at 1000 or $2000 \mathrm{ppm}$ on values of tuber yield/plant, marketable yield, nonmarketable yield and total yield in both growing seasons, also there were no significant differences between foliar spray with calcium at 1000 or 2000 ppm plus applied $\mathrm{K}_{2} \mathrm{O}$ at 48 or $72 \mathrm{~kg} / \mathrm{fed}$. and foliar spray with calcium at $0 \mathrm{ppm}$ (control) plus applied $\mathrm{K}_{2} \mathrm{O}$ at $72 \mathrm{~kg} / \mathrm{fed}$. on number of tuber/plant, in both growing seasons and there were no significant differences between foliar spray with calcium at 1000 or $2000 \mathrm{ppm}$ plus applied $\mathrm{K}_{2} \mathrm{O}$ at $0 \mathrm{~kg} / \mathrm{fed}$. (control) and foliar spray with calcium at $0 \mathrm{ppm}$ (control) plus applied $\mathrm{K}_{2} \mathrm{O}$ at $48 \mathrm{~kg} / \mathrm{fed}$. on number of tuber/plant, in the first season. Similar results were reported by Gashti et al. (2012) on peanut (Arachis 
hypogaea L.), they showed that the yield of pod and application along with potassium.

kernel increased with increasing of calcium

Table 8. Yield and its components of sweet potato plants as affected by the interactions between calcium and potassium at different rates during 2011 and 2012 growing seasons.

\begin{tabular}{|c|c|c|c|c|c|c|c|c|c|c|c|}
\hline \multirow{3}{*}{\multicolumn{2}{|c|}{ Treatments }} & \multicolumn{10}{|c|}{ Parameters } \\
\hline & & \multicolumn{4}{|c|}{ Yield/plant } & & & \multirow{2}{*}{\multicolumn{2}{|c|}{$\begin{array}{l}\text { Yield/plant } \\
\text { Non- } \\
\text { marketable } \\
\text { yield } \\
\text { (ton/fed.) }\end{array}$}} & \multirow{2}{*}{\multicolumn{2}{|c|}{$\begin{array}{l}\text { Total yield } \\
\text { (ton/fed.) }\end{array}$}} \\
\hline & & \multicolumn{2}{|l|}{$\begin{array}{l}\text { Weight } \\
\text { (g) }\end{array}$} & \multicolumn{2}{|c|}{ Number of tubers/plant } & \multicolumn{2}{|c|}{$\begin{array}{c}\text { Marketable } \\
\text { yield } \\
\text { (ton/fed.) }\end{array}$} & & & & \\
\hline Ca. & Po. & 2011 & 2012 & 2011 & 2012 & 2011 & 2012 & 2011 & 2012 & 2011 & 2012 \\
\hline$\overline{0}$ & Control & $762.17 \mathrm{~g}$ & $844.05 \mathrm{f}$ & $3.33 \mathrm{~b}$ & $3.57 \mathrm{~d}$ & $11.32 \mathrm{~g}$ & $10.90 \mathrm{~g}$ & $1.50 \mathrm{a}$ & $1.70 \mathrm{a}$ & $12.83 \mathrm{~g}$ & $12.61 \mathrm{f}$ \\
\hline 芫 & $\begin{array}{c}48 \mathrm{~kg} \\
\mathrm{~K}_{2} \mathrm{O} / \mathrm{fed} . \\
\end{array}$ & $883.28 \mathrm{~d}$ & $909.82 \mathrm{~d}$ & $3.88 \mathrm{ab}$ & $4.06 \mathrm{bcd}$ & $12.93 \mathrm{e}$ & $11.88 \mathrm{e}$ & $1.35 \mathrm{~b}$ & $1.53 \mathrm{~b}$ & $14.29 \mathrm{e}$ & $13.41 \mathrm{e}$ \\
\hline & $\begin{array}{c}72 \mathrm{~kg} \\
\mathrm{~K}_{2} \mathrm{O} / \mathrm{fed} .\end{array}$ & $1020.33 \mathrm{~b}$ & $948.82 \mathrm{~b}$ & $4.31 \mathrm{a}$ & $4.66 \mathrm{ab}$ & $13.97 \mathrm{c}$ & $13.11 \mathrm{~b}$ & $1.11 \mathrm{~d}$ & $1.26 \mathrm{~d}$ & $15.08 \mathrm{~b}$ & $14.37 \mathrm{~b}$ \\
\hline हूँ & Control & $784.94 \mathrm{f}$ & $874.04 \mathrm{e}$ & $3.66 \mathrm{ab}$ & $3.88 \mathrm{~cd}$ & $12.65 \mathrm{f}$ & $11.36 \mathrm{f}$ & $1.26 \mathrm{c}$ & $1.48 \mathrm{c}$ & $13.92 \mathrm{f}$ & $12.84 \mathrm{f}$ \\
\hline$\stackrel{2}{8}$ & $\begin{array}{c}48 \mathrm{~kg} \\
\mathrm{~K}_{2} \mathrm{O} / \mathrm{fed} . \\
\end{array}$ & $926.18 \mathrm{c}$ & $934.92 \mathrm{c}$ & $4.02 \mathrm{ab}$ & $4.31 \mathrm{abc}$ & $13.98 \mathrm{c}$ & $12.78 \mathrm{c}$ & $1.08 \mathrm{~d}$ & $1.18 \mathrm{f}$ & $15.07 \mathrm{~b}$ & $13.97 \mathrm{~cd}$ \\
\hline & $\begin{array}{c}72 \mathrm{~kg} \\
\mathrm{~K}_{2} \mathrm{O} / \mathrm{fed} .\end{array}$ & $1043.46 \mathrm{a}$ & $976.23 \mathrm{a}$ & $4.37 \mathrm{a}$ & $4.77 \mathrm{a}$ & $14.41 \mathrm{a}$ & $14.16 \mathrm{a}$ & $0.82 \mathrm{f}$ & $0.99 \mathrm{~h}$ & $15.24 \mathrm{a}$ & $15.15 \mathrm{a}$ \\
\hline E्ב & Control & $820.97 \mathrm{e}$ & $898.71 \mathrm{~d}$ & $4.06 \mathrm{ab}$ & $4.06 \mathrm{bcd}$ & $13.63 \mathrm{~d}$ & $12.46 \mathrm{~d}$ & $1.12 \mathrm{~d}$ & $1.23 \mathrm{e}$ & $14.75 \mathrm{~d}$ & $13.70 \mathrm{de}$ \\
\hline ஓి & $\begin{array}{c}48 \mathrm{~kg} \\
\mathrm{~K}_{2} \mathrm{O} / \text { fed. }\end{array}$ & $930.47 \mathrm{c}$ & $952.06 \mathrm{~b}$ & $4.20 \mathrm{a}$ & $4.48 \mathrm{abc}$ & $14.07 \mathrm{~b}$ & $13.12 \mathrm{~b}$ & $0.93 \mathrm{e}$ & $1.07 \mathrm{~g}$ & $15.00 \mathrm{c}$ & $14.19 \mathrm{bc}$ \\
\hline & $\begin{array}{c}72 \mathrm{~kg} \\
\mathrm{~K}_{2} \mathrm{O} / \mathrm{fed} .\end{array}$ & $1040.87 \mathrm{a}$ & $971.02 \mathrm{a}$ & $4.37 \mathrm{a}$ & $4.77 \mathrm{a}$ & $14.40 \mathrm{a}$ & $14.08 \mathrm{a}$ & $0.83 \mathrm{f}$ & $0.99 \mathrm{~h}$ & $15.24 \mathrm{a}$ & $15.07 \mathrm{a}$ \\
\hline
\end{tabular}

Means with the same letters are not significantly differed at 5\% according to Duncan's multiple range test.

Ca. $=$ Calcium \& Po. = Potassium.

Data illustrated in Table 9 show that total yield of sweet potato roots, marketable yield, plant tuber yield and number of tuber roots/plant significantly increased, while non-marketable yield significantly reduced, in both growing seasons, as a result of the interaction between calcium and antioxidants. The highest total yield, marketable yield and root yield/plant were obtained as a result of the interaction between foliar spray with calcium at 2000 ppm and foliar spray with ascorbic acid at $200 \mathrm{ppm}$ while the highest number of tuber roots/plant were obtained as a result of the interaction between foliar spray with calcium at $2000 \mathrm{ppm}$ and foliar spray with salicylic acid at $200 \mathrm{ppm}$. There were no significant differences between foliar spray with calcium at 0 (control) or 1000 or 2000 ppm plus foliar spray with salicylic acid or ascorbic acid at $200 \mathrm{ppm}$ on number of tuber roots/plant, in both growing seasons and foliar spray with calcium at 2000 ppm without antioxidants (control) on number of tuber roots/plant, in the first growing season. There were no significant differences between foliar spray with calcium at 1000 or 2000 ppm plus foliar spray with ascorbic acid at $200 \mathrm{ppm}$ on non-marketable yield, in the first growing season, also there were no significant differences between foliar spray with calcium at 0 (control) or 1000 ppm plus foliar spray with ascorbic acid at $200 \mathrm{ppm}$ and foliar spray with calcium at 2000 ppm plus foliar spray with salicylic acid or ascorbic acid at $200 \mathrm{ppm}$ on total yield, in the second growing season. These results are in agreement with those obtained by El-Sherbini (2011) concluded that spray tomato plants with boron at $50 \mathrm{mg} / \mathrm{l}$, calcium at $2000 \mathrm{mg} / \mathrm{l}$, salicylic acid at $100 \mathrm{mg} / \mathrm{l}$ (as antioxidant) and selenium at concentration of $50 \mathrm{mg} / \mathrm{l} \mathrm{mixed} \mathrm{with}$ vitamin $\mathrm{E}$ at concentration of $150 \mathrm{mg} / \mathrm{l}$ as foliar application improve tomato fruit yield (ton/fed.).

Data presented in Table 10 show the interaction effect between potassium and antioxidants on sweet potato yield and its components. This interaction caused significant increase in total yield, marketable yield/fed, plant tuber yield and number of tuber roots/plant, in both growing seasons. On the other hand, non-marketable yield was significantly reduced as a result of the interaction, in both growing seasons. It is notable that plants fertilized with $72 \mathrm{~kg}$ $\mathrm{K}_{2} \mathrm{O} /$ fed. with foliar sprayed with ascorbic acid at $200 \mathrm{ppm}$, achieved higher yield/fed, marketable yield and plant tuber yield compared with the control except number of tuber roots/plant, the highest values obtained by fertilizing with $72 \mathrm{~kg} \mathrm{~K}_{2} \mathrm{O} / \mathrm{fed}$. with foliar spray with salicylic acid at $200 \mathrm{ppm}$. There were no significant differences between applied $\mathrm{K}_{2} \mathrm{O}$ at $48 \mathrm{~kg} / \mathrm{fed}$. plus foliar sprayed with salicylic acid at $200 \mathrm{ppm}$ and applied $\mathrm{K}_{2} \mathrm{O}$ at 72 $\mathrm{kg} / \mathrm{fed}$. plus foliar spray with salicylic acid or ascorbic acid at $200 \mathrm{ppm}$ on number of tuber roots/plant, in both growing seasons, also there were no significant differences between applied $\mathrm{K}_{2} \mathrm{O}$ at 0 (control) or $72 \mathrm{~kg} / \mathrm{fed}$. plus foliar spray with salicylic acid at $200 \mathrm{ppm}$ and applied $\mathrm{K}_{2} \mathrm{O}$ at $48 \mathrm{~kg} / \mathrm{fed}$. plus foliar spray with ascorbic acid at $200 \mathrm{ppm}$ on number of tuber roots/plant, in the first growing season. Such results were previously explained by WuZhong et al. (1997) on taro, showed that $\mathrm{K}$ application improved the quality of the produce by increasing vitamin C (ascorbic acid) levels, Imas (1999) showed that applying $\mathrm{K}$ fertilizer to potato significantly increased the vitamin $\mathrm{C}$ contents and El-Morsy et al. (2010) on garlic, showed that the 
interactions between PK-rates and antioxidants had a significant effect on total yield and number of cloves/bulb in the second growing season only. Whereas, bulb weight, bulb diameter and clove weight were significantly affected by the interaction in both growing seasons.

Table 9. Yield and its components of sweet potato plants as affected by the interactions between calcium and some antioxidants; i.e., salicylic acid and ascorbic acid, separately at different rates during 2011 and 2012 growing seasons.

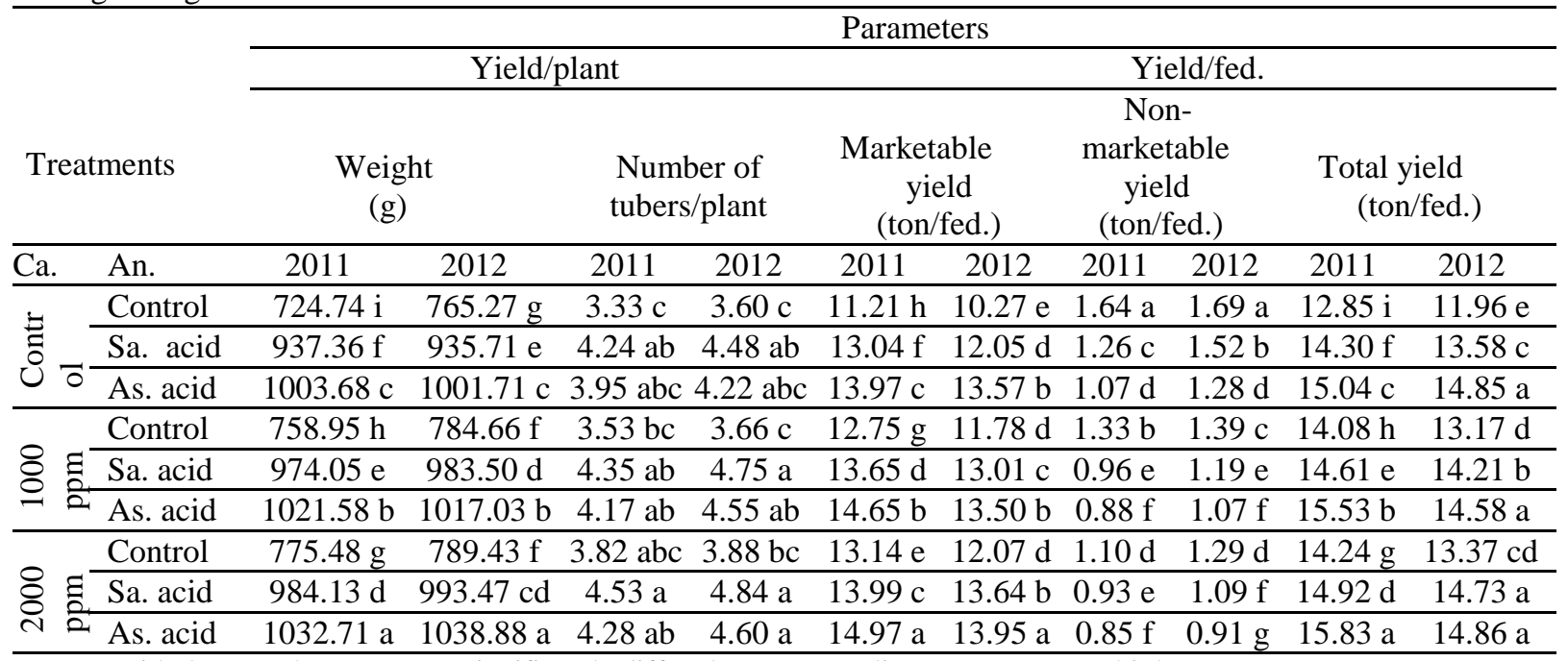

Means with the same letters are not significantly differed at 5\% according to Duncan's multiple range test.

Ca. $=$ Calcium \& An. $=$ Antioxidants \& Sa. acid $=$ Salicylic Acid \& As. acid = Ascorbic Acid.

Salicylic acid and Ascorbic acid were applied at $200 \mathrm{ppm}$.

Table 10. Yield and its components of sweet potato plants as affected by the interactions between potassium and some antioxidants; i.e., salicylic acid and ascorbic acid, separately at different rates during 2011 and 2012 growing seasons.

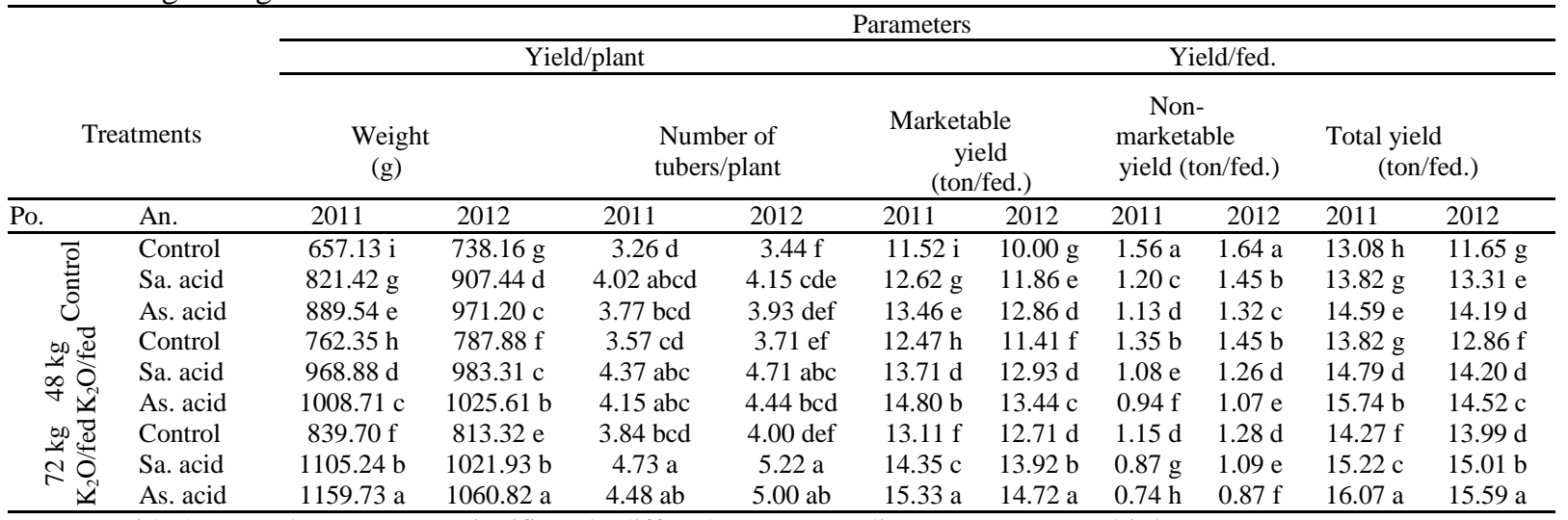

Means with the same letters are not significantly differed at 5\% according to Duncan's multiple range test.

Po. $=$ Potassium \& An. = Antioxidants \& Sa. acid = Salicylic Acid \& As. acid = Ascorbic Acid.

Salicylic acid and Ascorbic acid were applied at $200 \mathrm{ppm}$.

Interaction effect among all studied factors; i.e., calcium, potassium and antioxidants on sweet potato yield and its components was presented in Table 11. The data indicate that total yield, marketable yield, plant tuber yield and number of tuber roots/plant were significantly influenced by the interaction, in both growing seasons. On the other hand, nonmarketable yield was significantly reduced by the interaction, in both growing seasons. Plants sprayed with $1000 \mathrm{ppm}$ calcium, received potassium at $72 \mathrm{~kg}$ $\mathrm{K}_{2} \mathrm{O} /$ fed. plus sprayed with $200 \mathrm{ppm}$ ascorbic acid produced the highest total yield, marketable yield and plant tuber yield except number of tuber roots/plant in both growing seasons.

As for the interaction effect, it is obvious from the same data in Table 11 that all treatments were generally more effective in plants sprayed with 1000 ppm calcium than those sprayed with 2000 ppm calcium and the control. There were no significant differences between sprayed with 1000 ppm calcium, applied potassium at $72 \mathrm{~kg} \mathrm{~K}_{2} \mathrm{O} / \mathrm{fed}$. plus sprayed with $200 \mathrm{ppm}$ ascorbic acid and sprayed with 2000 ppm calcium, applied potassium at 48 or $72 \mathrm{~kg}$ $\mathrm{K}_{2} \mathrm{O} /$ fed. plus spray with 200 ppm ascorbic acid on 
plant tuber yield as a weight, in the second growing season. There were no significant differences between spray with $2000 \mathrm{ppm}$ calcium, applied potassium at 0 (control) or 48 or $72 \mathrm{~kg} \mathrm{~K} 2 \mathrm{O} / \mathrm{fed}$. plus spray with $200 \mathrm{ppm}$ salicylic acid or ascorbic acid and spray with 0 (control) or $1000 \mathrm{ppm}$ calcium, applied potassium at 0 (control) or 48 or $72 \mathrm{~kg}$ $\mathrm{K}_{2} \mathrm{O} /$ fed. plus spray with $200 \mathrm{ppm}$ salicylic acid or ascorbic acid on plant number of tuber roots/plant, in the first growing season, also there were no significant differences between spray with $2000 \mathrm{ppm}$ calcium, applied potassium at 0 (control) or 48 or 72 $\mathrm{kg} \mathrm{K}_{2} \mathrm{O} /$ fed. without antioxidants (control) and spray with 0 (control) or $1000 \mathrm{ppm}$ calcium, applied potassium at 48 or $72 \mathrm{~kg} \quad \mathrm{~K}_{2} \mathrm{O} /$ fed. without antioxidants (control) on plant number of tuber roots/plant, in the first growing season, on the other hand there were no significant differences between spray with 1000 or 2000 ppm calcium, applied potassium at 48 or $72 \mathrm{~kg} \mathrm{~K} 2 \mathrm{O} / \mathrm{fed}$. plus sprayed with $200 \mathrm{ppm}$ salicylic acid or ascorbic acid and spray with 0 (control) ppm calcium, applied potassium at $72 \mathrm{~kg} \mathrm{~K} \mathrm{~K}_{2} \mathrm{O} / \mathrm{fed}$. plus spray with $200 \mathrm{ppm}$ salicylic acid or ascorbic acid on plant number of tuber roots/plant, in the second growing season. Also there were no significant differences between sprayed with 1000 or $2000 \mathrm{ppm}$ calcium, applied potassium at 0 $\mathrm{kg} \mathrm{K} \mathrm{K}_{2} \mathrm{O} / \mathrm{fed}$. (control) plus sprayed with $200 \mathrm{ppm}$ salicylic acid and sprayed with 0 (control) ppm calcium, applied potassium at $48 \mathrm{~kg} \mathrm{~K}_{2} \mathrm{O} /$ fed. plus sprayed with $200 \mathrm{ppm}$ salicylic acid on plant number of tuber roots/plant, in the second growing season. There were no significant differences between sprayed with $1000 \mathrm{ppm}$ calcium, applied potassium at $72 \mathrm{~kg} \mathrm{~K} \mathrm{~K}_{2} \mathrm{O} / \mathrm{fed}$. plus spray with $200 \mathrm{ppm}$ ascorbic acid and spray with 0 (control) or 2000 ppm calcium, applied potassium at $72 \mathrm{~kg} \mathrm{~K}_{2} \mathrm{O} / \mathrm{fed}$. plus spray with $200 \mathrm{ppm}$ ascorbic acid on marketable yield, in the second growing season, on the other hand there were no significant differences between spray with 1000 or $2000 \mathrm{ppm}$ calcium, applied potassium at $72 \mathrm{~kg}$ $\mathrm{K}_{2} \mathrm{O} /$ fed. plus spray with $200 \mathrm{ppm}$ ascorbic acid and sprayed with $1000 \mathrm{ppm}$ calcium, applied potassium at $72 \mathrm{~kg} \mathrm{~K} \mathrm{~K}_{2} \mathrm{O} /$ fed. plus spray with 200 ppm salicylic acid on non-marketable yield, in the first growing season, while in the second season there were no significant differences between spray with $1000 \mathrm{ppm}$ calcium, applied potassium at $72 \mathrm{~kg} \mathrm{~K}_{2} \mathrm{O} /$ fed. plus spray with $200 \mathrm{ppm}$ ascorbic acid and spray with $2000 \mathrm{ppm}$ calcium, applied potassium at 48 or $72 \mathrm{~kg}$ $\mathrm{K}_{2} \mathrm{O} /$ fed. plus spray with $200 \mathrm{ppm}$ ascorbic acid, also for total yield there were no significant differences between spray with 1000 ppm calcium, applied potassium at $72 \mathrm{~kg} \mathrm{~K} \mathrm{~K}_{2} \mathrm{O} / \mathrm{fed}$. plus spray with 200 ppm ascorbic acid and spray with 2000 ppm calcium, applied potassium at $72 \mathrm{~kg} \mathrm{~K}_{2} \mathrm{O} / \mathrm{fed}$. plus spray with $200 \mathrm{ppm}$ ascorbic acid, in the first growing season, while in the second growing season there were no significant differences between spray with $1000 \mathrm{ppm}$ calcium, applied potassium at $72 \mathrm{~kg} \mathrm{~K}_{2} \mathrm{O} /$ fed. plus spray with 200 ppm salicylic acid or ascorbic acid and spray with 0 (control) or $2000 \mathrm{ppm}$ calcium, applied potassium at $72 \mathrm{~kg} \mathrm{~K} \mathrm{~K}_{2} \mathrm{O} / \mathrm{fed}$. plus spray with $200 \mathrm{ppm}$ ascorbic acid. The positive results of calcium on yield and its components might be due to that calcium is component of the middle lamella and is essential for intracellular membrane transport. Also, calcium is known to act as a signaling molecule that can regulate metabolism, controlling respiration, reducing ethylene production and mitigate the effect of heat and cold stresses on plant (Marschner, 2013). Potassium has an established reputation as a major controlling effect on tuber production in plant and it is the most important nutrient element needed by sweet potato in terms of nutrient uptake per unit area per unit tuber production. Since sweet potato is generally grown on highly weathered and leached soils where available $\mathrm{K}$ status is low, management of $\mathrm{K}$ assumes greatest significance (Byju and George, 2005). These results also, may be due to the simulative effect of ascorbic acid (Vit. C) which has a wide range of important functions as antioxidant defense, photoprotection, regulation of photosynthesis, affects nutritional cycle's activity in higher plants, electron transport system, as a cofactor for a large number of key enzymes in plants, also developmental senescence, programmed cell death and responses to pathogens (Blokhina et al., 2003).

\section{3- Tuber root characters:}

Data illustrated in Table 12 show the physical properties of sweet potato roots, expressed as weight, length, diameter, shape and dry matter of tuber root. Application of calcium rates resulted in significant increases in average weight, average root length, diameter and dry matter of tuber root, in both growing seasons, while root shape increased significantly in the second growing season only and there were no significant differences between spray with 1000 ppm calcium and spray with 2000 ppm calcium on root shape, in the first growing season. The improvement effect of calcium may be du to that it is an essential macronutrient required for plant growth and has been implicated as a factor influencing tuber quality (Lang et al., 1999). These results are accordance with those of Clough (1994) who found that potato size distribution, specific gravity and grade were significantly affected by $\mathrm{Ca}$ treatments.

Effect of potassium on tuber root characteristics was presented in Table 12. The obtained results revealed that weight, length, diameter and dry matter of tuber root were increased significantly as the applied potassium increased from 0 to $72 \mathrm{~kg}$ $\mathrm{K}_{2} \mathrm{O} /$ fed. in the two growing seasons. However, all tested potassium levels did not significantly affect shape of tuber roots in the first growing season only, but in the second one the increase was significant and the highest values obtained from the control in both 
growing seasons. The obtained increases in tuber root characteristics may be attributed to the role of potassium which has considered as a major controlling effect on tuber production in plant and it is the most important nutrient element needed by sweet potato in terms of nutrient uptake per unit area per unit tuber production. Since sweet potato is generally grown on highly weathered and leached soils where available $\mathrm{K}$ status is low, management of $\mathrm{K}$ assumes greatest significance (Byju and George, 2005). Similar results were reported by Abd ElBaky et al. (2010) showed that potassium played an important role in yield and quality of sweet potato.

Table 11. Yield and its components of sweet potato plants as affected by the interactions among calcium, potassium and some antioxidants; i.e., salicylic acid and ascorbic acid, separately at different rates during 2011 and 2012 growing seasons.

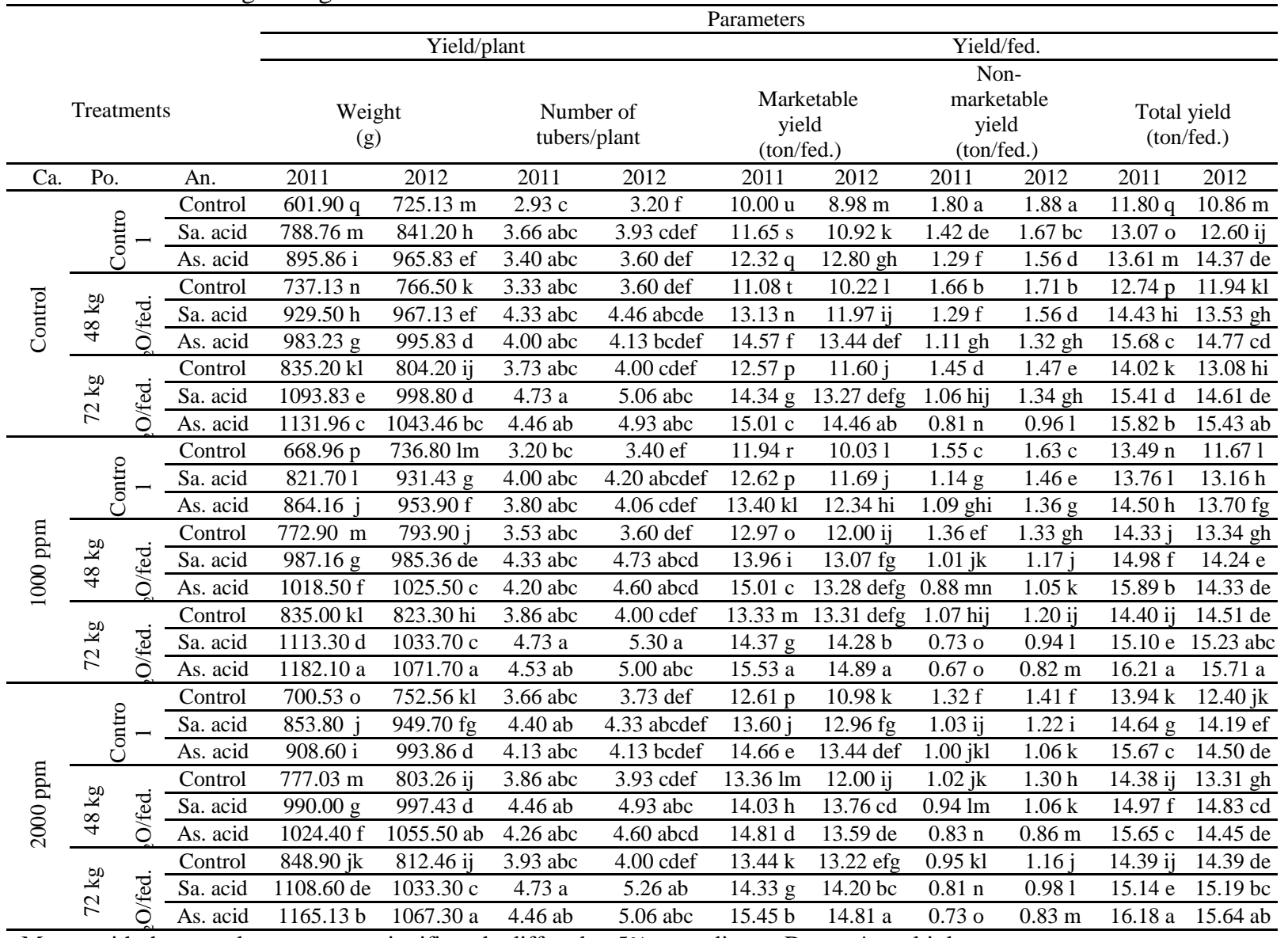

Means with the same letters are not significantly differed at $5 \%$ according to Duncan's multiple range test.

Ca. $=$ Calcium \& Po. = Potassium \& An. = Antioxidants \& Sa. acid = Salicylic Acid \& As. acid = Ascorbic Acid.

Salicylic acid and Ascorbic acid were applied at $200 \mathrm{ppm}$.

Concerning the effect of antioxidants on tuber root characteristics of sweet potato, data in Table 12 indicate that plants sprayed with antioxidants resulted in significant increase in weight, length, diameter, shape and dry matter of tuber root, in both growing seasons. The highest values of weight, length, diameter, shape and dry matter of tuber root were obtained from plants sprayed with ascorbic acid at $200 \mathrm{ppm}$ in both seasons. Such results may suggest that ascorbic acid (Vit. C) has a wide range of important functions as antioxidant defense, photoprotection, regulation of photosynthesis, affects nutritional cycle's activity in higher plants, electron transport system, as a cofactor for a large number of key enzymes in plants, also developmental senescence, programmed cell death and responses to pathogens (Blokhina et al., 2003). Some investigators came to nearly similar results, where El-Morsy et al. (2010) indicate that total yield and its components were better with foliar application of antioxidants comparing with the untreated ones. Moreover, application of ascorbic acid at $150 \mathrm{ppm}$ was more beneficial treatment to increase total yield and improving its components than the other substances of garlic (Allium sativum L.). 
Table 12. Tuber root characteristics of sweet potato plants as affected by calcium, potassium and some antioxidants; i.e., salicylic acid and ascorbic acid, separately at different rates during 2011 and 2012 growing seasons.

\begin{tabular}{|c|c|c|c|c|c|c|c|c|c|c|}
\hline \multirow{3}{*}{ Treatments } & \multicolumn{10}{|c|}{ Parameters } \\
\hline & \multicolumn{2}{|c|}{$\begin{array}{c}\text { Average } \\
\text { root weight } \\
(\mathrm{g})\end{array}$} & \multicolumn{2}{|c|}{$\begin{array}{l}\text { Average } \\
\text { root length } \\
(\mathrm{cm})\end{array}$} & \multicolumn{2}{|c|}{$\begin{array}{l}\text { Average } \\
\text { root diameter } \\
(\mathrm{cm})\end{array}$} & \multicolumn{2}{|c|}{$\begin{array}{c}\text { Root shape } \\
\text { (length/diameter) }\end{array}$} & \multicolumn{2}{|c|}{$\begin{array}{l}\text { Dry matter } \\
(\%)\end{array}$} \\
\hline & 2011 & 2012 & 2011 & 2012 & 2011 & 2012 & 2011 & 2012 & 2011 & 2012 \\
\hline \multicolumn{11}{|l|}{ Calcium } \\
\hline Control & $170.45 \mathrm{c}$ & $182.59 \mathrm{c}$ & $15.38 \mathrm{c}$ & $14.36 \mathrm{c}$ & $3.95 \mathrm{c}$ & $4.24 \mathrm{c}$ & $3.88 \mathrm{a}$ & $3.40 \mathrm{c}$ & $22.75 \mathrm{c}$ & $23.25 \mathrm{c}$ \\
\hline $1000 \mathrm{ppm}$ & $200.21 \mathrm{~b}$ & $204.77 \mathrm{~b}$ & $17.62 \mathrm{~b}$ & $17.25 \mathrm{~b}$ & $4.75 \mathrm{~b}$ & $4.92 \mathrm{~b}$ & $3.70 \mathrm{~b}$ & $3.50 \mathrm{~b}$ & $26.45 \mathrm{~b}$ & $26.51 \mathrm{~b}$ \\
\hline $2000 \mathrm{ppm}$ & $210.51 \mathrm{a}$ & $213.89 \mathrm{a}$ & $18.56 \mathrm{a}$ & $18.86 \mathrm{a}$ & $5.02 \mathrm{a}$ & $5.12 \mathrm{a}$ & $3.69 \mathrm{~b}$ & $3.68 \mathrm{a}$ & $27.75 \mathrm{a}$ & $28.31 \mathrm{a}$ \\
\hline \multicolumn{11}{|l|}{ Potassium } \\
\hline Control & $165.62 \mathrm{c}$ & $177.13 \mathrm{c}$ & $14.30 \mathrm{c}$ & $14.13 \mathrm{c}$ & $3.76 \mathrm{c}$ & $3.71 \mathrm{c}$ & $3.79 \mathrm{a}$ & $3.76 \mathrm{a}$ & $23.21 \mathrm{c}$ & $23.07 \mathrm{c}$ \\
\hline $48 \mathrm{~kg} \mathrm{~K}_{2} \mathrm{O} / \mathrm{fed}$ & $194.01 \mathrm{~b}$ & $204.07 \mathrm{~b}$ & $17.51 \mathrm{~b}$ & $16.66 \mathrm{~b}$ & $4.70 \mathrm{~b}$ & $5.08 \mathrm{~b}$ & $3.72 \mathrm{a}$ & $3.25 \mathrm{c}$ & $25.68 \mathrm{~b}$ & $26.21 \mathrm{~b}$ \\
\hline $72 \mathrm{~kg} \mathrm{~K}_{2} \mathrm{O} / \mathrm{fed}$ & $221.52 \mathrm{a}$ & $220.04 \mathrm{a}$ & $19.74 \mathrm{a}$ & $19.68 \mathrm{a}$ & $5.25 \mathrm{a}$ & $5.48 \mathrm{a}$ & $3.75 \mathrm{a}$ & $3.56 \mathrm{~b}$ & $28.05 \mathrm{a}$ & $28.78 \mathrm{a}$ \\
\hline \multicolumn{11}{|l|}{ Antioxidants } \\
\hline Control & $165.35 \mathrm{c}$ & $169.63 \mathrm{c}$ & $14.17 \mathrm{c}$ & $13.09 \mathrm{c}$ & $4.14 \mathrm{c}$ & $4.31 \mathrm{c}$ & $3.43 \mathrm{c}$ & $3.03 \mathrm{c}$ & $21.99 \mathrm{c}$ & $21.74 \mathrm{c}$ \\
\hline Salicylic acid & $200.52 \mathrm{~b}$ & $208.59 \mathrm{~b}$ & $17.80 \mathrm{~b}$ & $17.50 \mathrm{~b}$ & $4.70 \mathrm{~b}$ & $4.85 \mathrm{~b}$ & $3.80 \mathrm{~b}$ & $3.62 \mathrm{~b}$ & $26.31 \mathrm{~b}$ & $26.56 \mathrm{~b}$ \\
\hline Ascorbic acid & $215.28 \mathrm{a}$ & $223.02 \mathrm{a}$ & $19.57 \mathrm{a}$ & $19.87 \mathrm{a}$ & $4.87 \mathrm{a}$ & $5.10 \mathrm{a}$ & $4.04 \mathrm{a}$ & $3.92 \mathrm{a}$ & $28.64 \mathrm{a}$ & $29.77 \mathrm{a}$ \\
\hline
\end{tabular}

Data presented in Table 13 show the interaction effect between calcium and potassium on tuber root characteristics. Generally, there were significant effects for the interaction on weight, length, diameter and dry matter of tuber root. It was clear also that plants sprayed with calcium at $1000 \mathrm{ppm}$ and fertilized with $72 \mathrm{~kg} \mathrm{~K}_{2} \mathrm{O} / \mathrm{fed}$. gave the highest values of tuber root features except root shape, in both growing seasons, while the lowest values were obtained from the control plants that did not receive calcium or potassium fertilizer. There were no significant differences between spray with calcium at $1000 \mathrm{ppm}$ plus applied $72 \mathrm{~kg} \mathrm{~K}_{2} \mathrm{O} / \mathrm{fed}$. and spray with calcium at 2000 ppm plus applied $72 \mathrm{~kg}$ $\mathrm{K}_{2} \mathrm{O} /$ fed. on length and diameter of tuber root, in both growing season, and on weight and dry matter of tuber root, in the second growing season, also there were no significant differences between spray with calcium at 0 ppm (control) plus applied 0 or 48 or $72 \mathrm{~kg} \mathrm{~K} \mathrm{~K}_{2} \mathrm{O} / \mathrm{fed}$. and spray with calcium at 1000 ppm without $\mathrm{K}_{2} \mathrm{O}$ (control) on root shape, in the first growing season.

Table 13. Tuber root characteristics of sweet potato plants as affected by the interactions between calcium and potassium at different rates during 2011 and 2012 growing seasons.

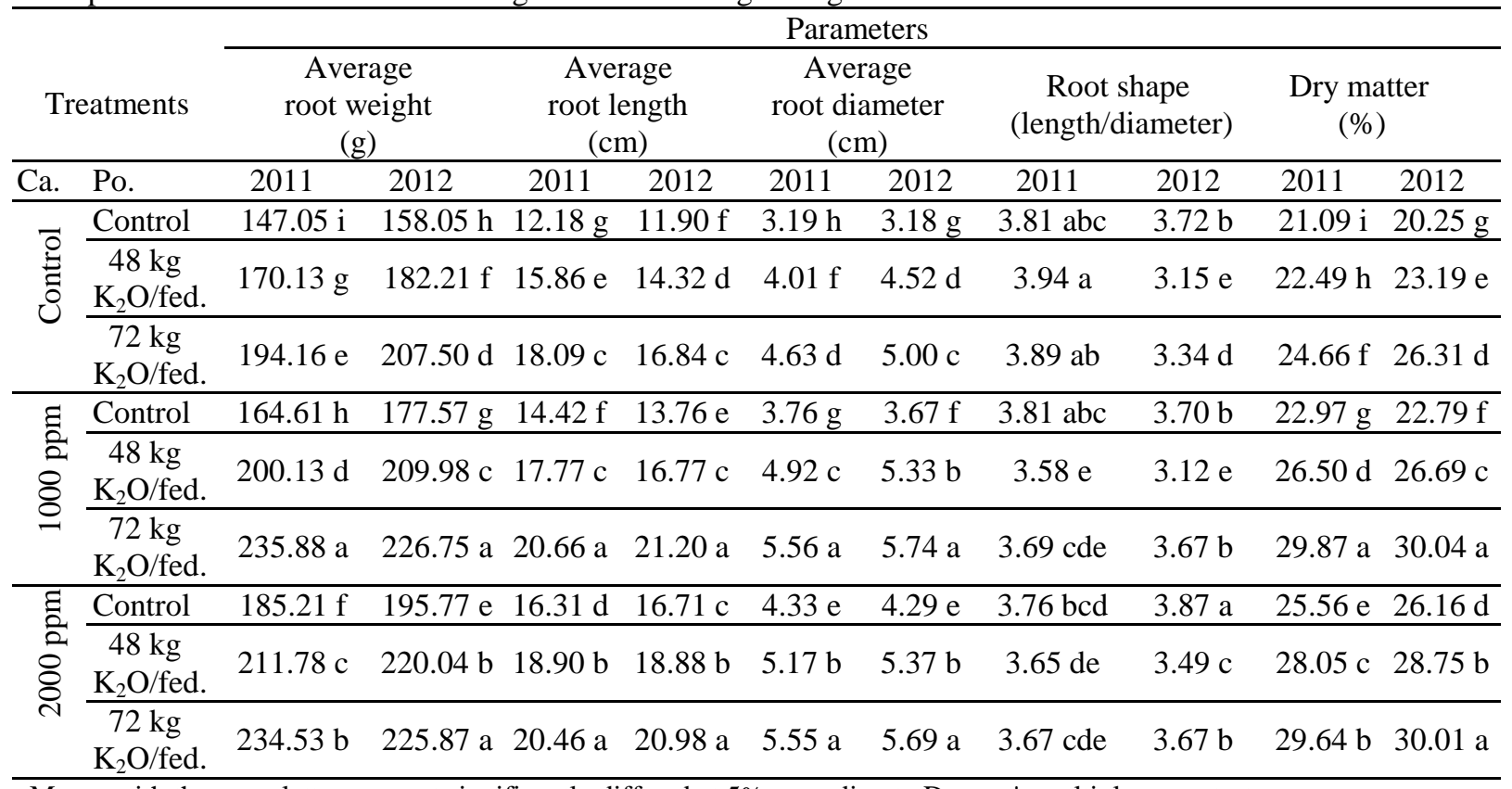

Means with the same letters are not significantly differed at 5\% according to Duncan's multiple range test.

Ca. $=$ Calcium \& Po. $=$ Potassium. 
It is evident from Table 14, that the interaction between calcium and antioxidants greatly affected most characteristics of sweet potato tuber roots. Average weight, length, diameter and dry matter of tuber root, in both growing seasons were significantly increased by foliar spray of calcium at $2000 \mathrm{ppm}$ in the presence of ascorbic acid at 200 ppm than in the absence of them (control). On the other hand, tuber root shape, in the first growing season was significantly increased in the absence of calcium in the presence of ascorbic acid at $200 \mathrm{ppm}$, but in the second growing season the highest value obtained from foliar spray of calcium at $1000 \mathrm{ppm}$ in the presence of ascorbic acid at $200 \mathrm{ppm}$. There were no significant differences between foliar spray of calcium at $2000 \mathrm{ppm}$ in the presence of ascorbic acid at $200 \mathrm{ppm}$ and foliar spray of calcium at $1000 \mathrm{ppm}$ in the presence of ascorbic acid at $200 \mathrm{ppm}$ on average length of tuber root, in the first growing season, also there were no significant differences between foliar spray of calcium at $2000 \mathrm{ppm}$ in the presence of ascorbic acid or salicylic acid at 200 ppm on average diameter of tuber root, in the first growing season, on the other hand, there were no significant differences between foliar spray of calcium at $1000 \mathrm{ppm}$ in the presence of ascorbic acid at $200 \mathrm{ppm}$ and foliar spray of calcium at $2000 \mathrm{ppm}$ in the presence of ascorbic acid at $200 \mathrm{ppm}$ on tuber root shape, in the second growing season. The superiority effect of the interaction between calcium and antioxidants could be explained in the light of the great roles played by calcium on plant growth and has been implicated as a factor influencing tuber quality (Lang et al., 1999), also calcium has attracted much interest in plant physiology and molecular biology because of its function as a second messenger in the signal conduction between environmental factors and plant responses in terms of growth and development (Reddy, 2001). Similar results were reported by Lin et al. (2008) they reported that the level of activity of the antioxidative system in sweet potato leaves was related to $\mathrm{CaCl}_{2}$ pretreatment during flooding. The ascorbate peroxidase, superoxide dismutase, glutathione reductase, reduced ascorbate, total ascorbate, reduced glutathione and malondialdehyde contents of the three sweet potato varieties under flooding stress significantly increased because of pretreatment with 60 and $120 \mathrm{~kg} \mathrm{ha}^{-1}$ of $\mathrm{CaCl}_{2}$.

Table 14. Tuber root characteristics of sweet potato plants as affected by the interactions between calcium and some antioxidants; i.e., salicylic acid and ascorbic acid, separately at different rates during 2011 and 2012 growing seasons.

\begin{tabular}{|c|c|c|c|c|c|c|c|c|c|c|c|}
\hline \multirow{2}{*}{\multicolumn{2}{|c|}{ Treatments }} & \multicolumn{10}{|c|}{ Parameters } \\
\hline & & \multicolumn{2}{|c|}{$\begin{array}{l}\text { Average } \\
\text { root weight } \\
(\mathrm{g})\end{array}$} & \multicolumn{2}{|c|}{$\begin{array}{l}\text { Average } \\
\text { root length } \\
\quad(\mathrm{cm})\end{array}$} & \multicolumn{2}{|c|}{$\begin{array}{l}\text { Average } \\
\text { root diameter } \\
(\mathrm{cm})\end{array}$} & \multicolumn{2}{|c|}{$\begin{array}{c}\text { Root shape } \\
\text { (length/diameter) }\end{array}$} & \multicolumn{2}{|c|}{$\begin{array}{l}\text { Dry matter } \\
\qquad(\%)\end{array}$} \\
\hline $\mathrm{Ca}$. & An. & 2011 & 2012 & 2011 & 2012 & 2011 & 2012 & 2011 & 2012 & 2011 & 2012 \\
\hline \multirow{3}{*}{ 孞 } & Control & $140.78 \mathrm{i}$ & $153.27 \mathrm{~h}$ & $12.71 \mathrm{~g}$ & $11.09 \mathrm{~h}$ & $3.56 \mathrm{f}$ & $3.70 \mathrm{~g}$ & $3.56 \mathrm{e}$ & $2.98 \mathrm{f}$ & $19.71 \mathrm{~h}$ & $19.51 \mathrm{i}$ \\
\hline & Sa. acid & $178.07 \mathrm{~g}$ & $189.77 \mathrm{f}$ & $15.55 \mathrm{e}$ & $14.94 \mathrm{f}$ & $4.07 \mathrm{e}$ & $4.36 \mathrm{f}$ & $3.83 \mathrm{~cd}$ & $3.48 \mathrm{~d}$ & $23.56 \mathrm{f}$ & $23.78 \mathrm{~g}$ \\
\hline & As. acid & $192.49 \mathrm{e}$ & $204.72 \mathrm{e}$ & $17.87 \mathrm{~d}$ & $17.04 \mathrm{e}$ & $4.21 \mathrm{e}$ & $4.64 \mathrm{~d}$ & $4.25 \mathrm{a}$ & $3.74 \mathrm{c}$ & $24.97 \mathrm{e}$ & $26.46 \mathrm{e}$ \\
\hline \multirow{3}{*}{ 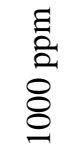 } & Control & $168.51 \mathrm{~h}$ & $166.32 \mathrm{~g}$ & $13.91 \mathrm{f}$ & $13.36 \mathrm{~g}$ & $4.38 \mathrm{~d}$ & $4.52 \mathrm{e}$ & $3.17 \mathrm{f}$ & $2.95 \mathrm{f}$ & $22.78 \mathrm{~g}$ & $21.63 \mathrm{~h}$ \\
\hline & Sa. acid & $209.59 \mathrm{~d}$ & $216.98 \mathrm{~d}$ & $18.64 \mathrm{c}$ & $17.74 \mathrm{~d}$ & $4.82 \mathrm{c}$ & $5.04 \mathrm{c}$ & $3.88 \mathrm{c}$ & $3.52 \mathrm{~d}$ & $26.74 \mathrm{~d}$ & $27.06 \mathrm{~d}$ \\
\hline & As. acid & $222.51 \mathrm{~b}$ & $231.00 \mathrm{~b}$ & $20.30 \mathrm{a}$ & $20.64 \mathrm{~b}$ & $5.04 \mathrm{~b}$ & $5.18 \mathrm{~b}$ & $4.04 \mathrm{~b}$ & $4.02 \mathrm{a}$ & $29.82 \mathrm{~b}$ & $30.83 \mathrm{~b}$ \\
\hline \multirow{3}{*}{ 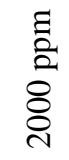 } & Control & $186.77 \mathrm{f}$ & $189.29 \mathrm{f}$ & $15.91 \mathrm{e}$ & $14.83 \mathrm{f}$ & $4.48 \mathrm{~d}$ & $4.72 \mathrm{~d}$ & $3.56 \mathrm{e}$ & $3.15 \mathrm{e}$ & $23.48 \mathrm{f}$ & $24.08 \mathrm{f}$ \\
\hline & Sa. acid & $213.89 \mathrm{c}$ & $219.03 \mathrm{c}$ & $19.21 \mathrm{~b}$ & $19.81 \mathrm{c}$ & $5.21 \mathrm{a}$ & $5.16 \mathrm{~b}$ & $3.68 \mathrm{de}$ & $3.87 \mathrm{~b}$ & $28.62 \mathrm{c}$ & $28.83 \mathrm{c}$ \\
\hline & As. acid & $230.85 \mathrm{a}$ & $233.35 \mathrm{a}$ & $20.55 \mathrm{a}$ & $21.94 \mathrm{a}$ & $5.36 \mathrm{a}$ & $5.47 \mathrm{a}$ & $3.83 \mathrm{c}$ & $4.01 \mathrm{a}$ & $31.15 \mathrm{a}$ & $32.01 \mathrm{a}$ \\
\hline
\end{tabular}

Means with the same letters are not significantly differed at 5\% according to Duncan's multiple range test.

Ca. $=$ Calcium \& An. $=$ Antioxidants \& Sa. acid $=$ Salicylic Acid \& As. acid $=$ Ascorbic Acid.

Salicylic acid and Ascorbic acid were applied at $200 \mathrm{ppm}$.

Data illustrated in Table 15 reveal that average root weight, length, diameter, shape and dry matter of tuber root were significantly increased, in both growing seasons, by the interaction between potassium and antioxidants. In general, plants fertilized with $72 \mathrm{~kg} \mathrm{~K} \mathrm{~K}_{2} \mathrm{O} / \mathrm{fed}$. in the presence of ascorbic acid at $200 \mathrm{ppm}$, almost gave the highest values of tuber root features, except root shape, in both growing seasons, plants sprayed with ascorbic acid at $200 \mathrm{ppm}$ in the absence of potassium gave the highest values of root shape, in both growing seasons. Also there were no significant differences between applied $72 \mathrm{~kg} \mathrm{~K}_{2} \mathrm{O} / \mathrm{fed}$. in the presence of salicylic acid at $200 \mathrm{ppm}$ and applied $72 \mathrm{~kg} \mathrm{~K}_{2} \mathrm{O} / \mathrm{fed}$. in the presence of ascorbic acid at $200 \mathrm{ppm}$ on average root diameter, in the first growing season. 
The significant increase in average tuber root weight may be due to that potassium is an essential plant nutrient that plays a very important role in plant growth and development. Its role is well documented in photosynthesis, increasing enzyme activity, improving synthesis of protein, carbohydrates and fats, translocation of sugars, enabling their ability to rest pests and diseases (Dkhil et al., 2011). Also, potassium is considered as major osmotically active cation of plant cell where it enhances water uptake and root permeability and acts as guard cell controller, beside its role in increasing water use efficiency (Mengel and Kirkby, 1987). These results are in harmony with those of WuZhong $\boldsymbol{e t}$ al. (1997) they found that $K$ application improved the yield and quality of the produce of onion and taro by increasing vitamin C (ascorbic acid) levels, and ElMorsy et al. (2010) they showed that the interactions between PK-rates and antioxidants had a significant effect on bulb weight, bulb diameter and clove weight.

Table 15. Tuber root characteristics of sweet potato plants as affected by the interactions between potassium and some antioxidants; i.e., salicylic acid and ascorbic acid, separately at different rates during 2011 and 2012 growing seasons.

\begin{tabular}{|c|c|c|c|c|c|c|c|c|c|c|c|}
\hline \multirow{2}{*}{\multicolumn{2}{|c|}{ Treatments }} & \multicolumn{10}{|c|}{ Parameters } \\
\hline & & \multicolumn{2}{|c|}{$\begin{array}{c}\text { Average } \\
\text { root weight } \\
(\mathrm{g})\end{array}$} & \multicolumn{2}{|c|}{$\begin{array}{l}\text { Average } \\
\text { root length } \\
(\mathrm{cm})\end{array}$} & \multicolumn{2}{|c|}{$\begin{array}{c}\text { Average } \\
\text { root diameter } \\
(\mathrm{cm})\end{array}$} & \multicolumn{2}{|c|}{$\begin{array}{c}\text { Root shape } \\
\text { (length/diameter) }\end{array}$} & \multicolumn{2}{|c|}{$\begin{array}{c}\text { Dry matter } \\
(\%)\end{array}$} \\
\hline Po. & An. & 2011 & 2012 & 2011 & 2012 & 2011 & 2012 & 2011 & 2012 & 2011 & 2012 \\
\hline \multirow{3}{*}{$\begin{array}{l}0 \\
0 \\
0 \\
0\end{array}$} & Control & $138.79 \mathrm{i}$ & $150.90 \mathrm{i}$ & $11.71 \mathrm{~h}$ & $10.67 \mathrm{i}$ & $3.44 \mathrm{f}$ & $3.47 \mathrm{~h}$ & $3.39 \mathrm{e}$ & $3.05 \mathrm{f}$ & $20.12 \mathrm{~h}$ & $18.80 \mathrm{~h}$ \\
\hline & Sa. acid & $170.68 \mathrm{~g}$ & $183.24 \mathrm{~g}$ & $14.73 \mathrm{f}$ & $14.71 \mathrm{~g}$ & $3.85 \mathrm{e}$ & $3.71 \mathrm{~g}$ & $3.84 \mathrm{c}$ & $3.94 \mathrm{~b}$ & $23.97 \mathrm{e}$ & $23.48 \mathrm{f}$ \\
\hline & As. acid & $187.41 \mathrm{f}$ & $197.25 \mathrm{e}$ & $16.47 \mathrm{e}$ & $17.00 \mathrm{e}$ & $3.99 \mathrm{e}$ & $3.96 \mathrm{f}$ & $4.15 \mathrm{a}$ & $4.30 \mathrm{a}$ & $25.53 \mathrm{~d}$ & $26.92 \mathrm{~d}$ \\
\hline \multirow{3}{*}{ 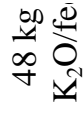 } & Control & $166.26 \mathrm{~h}$ & $171.41 \mathrm{~h}$ & $14.28 \mathrm{~g}$ & $13.17 \mathrm{~h}$ & $4.29 \mathrm{~d}$ & $4.38 \mathrm{e}$ & $3.36 \mathrm{e}$ & $3.00 \mathrm{f}$ & $22.10 \mathrm{~g}$ & $22.01 \mathrm{~g}$ \\
\hline & Sa. acid & $199.73 \mathrm{~d}$ & $213.70 \mathrm{~d}$ & $18.25 \mathrm{~d}$ & $17.52 \mathrm{~d}$ & $4.78 \mathrm{c}$ & $5.29 \mathrm{c}$ & $3.82 \mathrm{c}$ & $3.30 \mathrm{e}$ & 26.26 & $26.84 \mathrm{~d}$ \\
\hline & As. acid & $216.05 \mathrm{c}$ & $227.11 \mathrm{c}$ & $19.99 \mathrm{c}$ & $19.27 \mathrm{c}$ & $5.04 \mathrm{~b}$ & $5.55 \mathrm{~b}$ & $3.99 \mathrm{~b}$ & $3.46 \mathrm{~d}$ & $28.68 \mathrm{~b}$ & $29.78 \mathrm{~b}$ \\
\hline \multirow{3}{*}{ 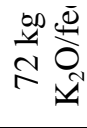 } & Control & $191.02 \mathrm{e}$ & $186.58 \mathrm{f}$ & $16.53 \mathrm{e}$ & $15.43 \mathrm{f}$ & $4.69 \mathrm{c}$ & $5.09 \mathrm{~d}$ & $3.54 \mathrm{~d}$ & $3.03 \mathrm{f}$ & $23.75 \mathrm{f}$ & $24.40 \mathrm{e}$ \\
\hline & Sa. acid & $231.15 \mathrm{~b}$ & $228.83 \mathrm{~b}$ & $20.42 \mathrm{~b}$ & $20.25 \mathrm{~b}$ & $5.47 \mathrm{a}$ & $5.56 \mathrm{~b}$ & $3.73 \mathrm{c}$ & $3.63 \mathrm{c}$ & $28.70 \mathrm{~b}$ & $29.36 \mathrm{c}$ \\
\hline & As. acid & $242.39 \mathrm{a}$ & $244.70 \mathrm{a}$ & $22.26 \mathrm{a}$ & $23.34 \mathrm{a}$ & $5.59 \mathrm{a}$ & $5.78 \mathrm{a}$ & $3.98 \mathrm{~b}$ & $4.02 \mathrm{~b}$ & $31.72 \mathrm{a}$ & $32.59 \mathrm{a}$ \\
\hline
\end{tabular}

Means with the same letters are not significantly differed at 5\% according to Duncan's multiple range test.

Po. $=$ Potassium \& An. $=$ Antioxidants $\&$ Sa. acid $=$ Salicylic Acid $\&$ As. acid $=$ Ascorbic Acid .

Salicylic acid and Ascorbic acid were applied at $200 \mathrm{ppm}$.

Results presented in Table 16 show the effect of the interaction among all studied factors viz. calcium, potassium and antioxidants on tuber root characteristics of sweet potato. The obtained results indicate that all characteristics of tuber root were significantly affected by the three ways interaction, in both growing seasons. Plants sprayed with calcium at $1000 \mathrm{ppm}$, supplied with $72 \mathrm{~kg} \mathrm{~K}_{2} \mathrm{O} / \mathrm{fed}$. and sprayed with ascorbic acid at $200 \mathrm{ppm}$ achieved great values accept root shape, in both growing seasons. The highest value of root shape obtained from sprayed with calcium at $0 \mathrm{ppm}$ (control), supplied with $48 \mathrm{~kg} \mathrm{~K}_{2} \mathrm{O} / \mathrm{fed}$. and sprayed with ascorbic acid at $200 \mathrm{ppm}$, in the first growing season while in the second growing season, the highest value obtained from spray with calcium at $1000 \mathrm{ppm}$, without $\mathrm{K}_{2} \mathrm{O}$ (control) and spray with ascorbic acid at $200 \mathrm{ppm}$, also there were no significant differences between spray with calcium at $0 \mathrm{ppm}$ (control), supplied with $48 \mathrm{~kg} \mathrm{~K}{ }_{2} \mathrm{O} / \mathrm{fed}$. and spray with ascorbic acid at 200 $\mathrm{ppm}$ and sprayed with calcium at $0 \mathrm{ppm}$ (control) or $1000 \mathrm{ppm}$, without $\mathrm{K}_{2} \mathrm{O}$ (control) and spray with ascorbic acid at $200 \mathrm{ppm}$ on root shape, in the first growing season but in the second growing season, there were no significant differences between spray with calcium at $1000 \mathrm{ppm}$, without $\mathrm{K}_{2} \mathrm{O}$ (control) and spray with ascorbic acid at $200 \mathrm{ppm}$ and spray with calcium at 0 ppm (control), without $\mathrm{K}_{2} \mathrm{O}$ (control) and spray with ascorbic acid at $200 \mathrm{ppm}$ on root shape. Also, there were no significant differences between spray with calcium at 1000 ppm, with 72 $\mathrm{K}_{2} \mathrm{O}$ and sprayed with ascorbic acid at $200 \mathrm{ppm}$ and spray with calcium at $2000 \mathrm{ppm}$, with $72 \mathrm{~K}_{2} \mathrm{O}$ and sprayed with ascorbic acid at $200 \mathrm{ppm}$ on average root length, in both growing seasons, on the other hand, there were no significant differences between spray with calcium at $1000 \mathrm{ppm}$, with $72 \mathrm{~K}_{2} \mathrm{O}$ and sprayed with salicylic acid or ascorbic acid at 200 ppm and spray with calcium at 2000 ppm, with 72 $\mathrm{K}_{2} \mathrm{O}$ and spray with salicylic acid or ascorbic acid at $200 \mathrm{ppm}$ on average root diameter, in the first growing season, while in the second growing season there were no significant differences between spray with calcium at 1000 ppm, with $72 \mathrm{~K}_{2} \mathrm{O}$ and spray with ascorbic acid at $200 \mathrm{ppm}$ and sprayed with calcium at $2000 \mathrm{ppm}$, with $72 \mathrm{~K}_{2} \mathrm{O}$ and sprayed with ascorbic acid at $200 \mathrm{ppm}$ on average root diameter. For dry matter of tuber root, there were no significant differences between spray with calcium at $1000 \mathrm{ppm}$, with $72 \mathrm{~K}_{2} \mathrm{O}$ and spray with salicylic acid or ascorbic acid at $200 \mathrm{ppm}$ and spray with calcium at $2000 \mathrm{ppm}$, with $72 \mathrm{~K}_{2} \mathrm{O}$ and spray with salicylic acid or ascorbic acid at $200 \mathrm{ppm}$, in the second growing seasons. 
Table 16. Tuber root characteristics of sweet potato plants as affected by the interactions among calcium, potassium and some antioxidants; i.e., salicylic acid and ascorbic acid, separately at different rates during 2011 and 2012 growing seasons.

\begin{tabular}{|c|c|c|c|c|c|c|c|c|c|c|c|}
\hline \multirow{2}{*}{\multicolumn{3}{|c|}{ Treatments }} & \multicolumn{9}{|c|}{ Parameters } \\
\hline & & & $\begin{array}{l}\text { Average } \\
\text { root weight } \\
(\mathrm{g})\end{array}$ & \multicolumn{2}{|c|}{$\begin{array}{l}\text { Average } \\
\text { root length } \\
(\mathrm{cm})\end{array}$} & \multicolumn{2}{|c|}{$\begin{array}{c}\text { Average } \\
\text { root diameter } \\
(\mathrm{cm})\end{array}$} & \multicolumn{2}{|c|}{$\begin{array}{c}\text { Root shape } \\
\text { (length/diameter) }\end{array}$} & \multicolumn{2}{|c|}{$\begin{array}{c}\text { Dry matter } \\
(\%)\end{array}$} \\
\hline Ca. & 0. & An. & 2012 & 2011 & 2012 & 2011 & 2012 & 2011 & 2012 & 2011 & 2012 \\
\hline \multirow{12}{*}{ 芯 } & \multirow{3}{*}{$\begin{array}{l}\bar{O} \\
\stackrel{\Xi}{0} \\
0\end{array}$} & $\mathrm{C}$ & 48 v 129.5 & 9.98 o & $8.77 \mathrm{o}$ & $\mathrm{p}$ & $\mathrm{n}$ & $3.23 \mathrm{k}$ & o & $8.29 \mathrm{t}$ & 16.6 \\
\hline & & Sa. acid & $154.25 \mathrm{~s} 166.97 \mathrm{p}$ & $12.47 \mathrm{~m}$ & 12.811 & $3.21 \mathrm{p}$ & $3.23 \mathrm{mn}$ & $3.89 \mathrm{cdef}$ & $3.96 \mathrm{~d}$ & $21.64 \mathrm{p}$ & $21.21 \mathrm{q}$ \\
\hline & & As. acid & $169.42 \mathrm{p} 177.69 \mathrm{o}$ & $14.10 \mathrm{k}$ & $14.13 \mathrm{j}$ & 3.28 op & $3.26 \mathrm{~m}$ & $4.31 \mathrm{ab}$ & $4.33 \mathrm{ab}$ & $23.34 \mathrm{n}$ & $22.91 \mathrm{n}$ \\
\hline & \multirow{3}{*}{ 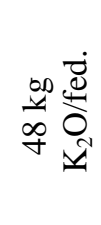 } & Control & 138.27 t 150.35 r & $\begin{array}{l}12.88 \\
\operatorname{lm}\end{array}$ & $11.11 \mathrm{~m}$ & $61 \mathrm{mn}$ & 3.691 & $3.62 \mathrm{ghi}$ & 3.0 & $19.88 \mathrm{~s}$ & $19.57 \mathrm{r}$ \\
\hline & & & $176.64 \mathrm{r}$ & $15.58 \mathrm{j}$ & $14.88 \mathrm{i}$ & $4.08 \mathrm{jk}$ & $4.64 \mathrm{~g}$ & $\begin{array}{c}3.82 \\
\text { cdefg }\end{array}$ & $3.20 \mathrm{jk}$ & 23.25 & 23. \\
\hline & & As. acid & $195.49 \mathrm{k} 207.21 \mathrm{~h}$ & $19.12 \mathrm{f}$ & $16.97 \mathrm{fg}$ & $4.35 \mathrm{ij}$ & $5.23 \mathrm{f}$ & $4.39 \mathrm{a}$ & $3.24 \mathrm{j}$ & $24.35 \mathrm{~m}$ & 26.3 \\
\hline & \multirow{4}{*}{ 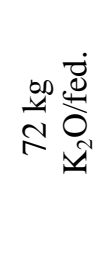 } & Control & 166.58 q179.98 n & $15.26 \mathrm{j}$ & $13.40 \mathrm{kl}$ & $3.98 \mathrm{kl}$ & $4.36 \mathrm{~h}$ & $\begin{array}{l}3.84 \\
\text { cdefg }\end{array}$ & $\mathrm{klm}$ & 20 & 22 \\
\hline & & Sa. acid & $203.32 \mathrm{j} 213.27 \mathrm{~g}$ & $18.61 \mathrm{fg}$ & $\begin{array}{c}17.13 \\
\text { efg }\end{array}$ & $4.91 \mathrm{efg}$ & $5.21 \mathrm{f}$ & 3.79 defg & $3.28 \mathrm{ij}$ & $25.80 \mathrm{k}$ & 26.4 \\
\hline & & As. acid & $212.57 \mathrm{~g} 229.25 \mathrm{e}$ & $20.40 \mathrm{~cd}$ & $20.01 \mathrm{~cd}$ & $5.02 \mathrm{de}$ & $5.44 \mathrm{de}$ & $4.06 \mathrm{bc}$ & 3.67 efg & $27.22 \mathrm{~h}$ & 30.0 \\
\hline & & Control & $135.63 \mathrm{u} 146.58 \mathrm{~s}$ & $1.25 \mathrm{n}$ & $10.22 \mathrm{n}$ & 3.50 no & $3.38 \mathrm{~m}$ & $3.21 \mathrm{k}$ & $3.02 \mathrm{lmn}$ & $20.36 \mathrm{r}$ & $17.97 \mathrm{~s}$ \\
\hline & Ö & Sa. & 171.67 o $\begin{array}{c}184.18 \\
\mathrm{~m}\end{array}$ & $15.08 \mathrm{j}$ & $13.77 \mathrm{jk}$ & $3.78 \mathrm{~lm}$ & $3.76 \mathrm{kl}$ & $3.99 \mathrm{~cd}$ & $3.65 \mathrm{fg}$ & $23.34 \mathrm{n}$ & $22.95 \mathrm{n}$ \\
\hline & & As & $\begin{array}{c}186.54 \\
\mathrm{~m}\end{array} 201.97 \mathrm{i}$ & $16.92 \mathrm{hi}$ & $17.31 \mathrm{ef}$ & $3.99 \mathrm{kl}$ & $3.89 \mathrm{jk}$ & $4.24 \mathrm{ab}$ & $4.45 \mathrm{a}$ & 25.201 & $27.45 \mathrm{~h}$ \\
\hline \multirow{9}{*}{$\begin{array}{l}2 \\
2 \\
8 \\
0\end{array}$} & \multirow{3}{*}{ 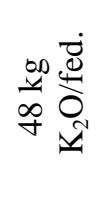 } & Control & $167.23 \mathrm{q} 164.27 \mathrm{q}$ & $13.52 \mathrm{kl}$ & $13.27 \mathrm{kl}$ & $4.60 \mathrm{hi}$ & $4.70 \mathrm{~g}$ & 2.931 & $2.82 \mathrm{o}$ & $22.94 \mathrm{o}$ & $21.71 \mathrm{p}$ \\
\hline & & Sa. acid & 210.51 h $228.73 \mathrm{e}$ & $19.26 \mathrm{ef}$ & $17.62 \mathrm{e}$ & $4.96 \mathrm{def}$ & $5.61 \mathrm{cde}$ & $3.88 \mathrm{cdef}$ & $3.14 \mathrm{jklm}$ & $26.61 \mathrm{j}$ & $27.30 \mathrm{~h}$ \\
\hline & & A & $222.64 \mathrm{f} \begin{array}{c}236.93 \\
\mathrm{~cd}\end{array}$ & $20.53 \mathrm{~cd}$ & $19.42 \mathrm{~d}$ & $5.20 \mathrm{~cd}$ & $5.69 \mathrm{c}$ & de & hi & 29.96 & 31.0 \\
\hline & \multirow{3}{*}{ 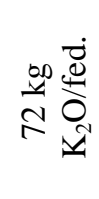 } & rol & 202.69 j 188.1 & $5.97 \mathrm{hi}$ & 16.59 & $5.03 \mathrm{cde}$ & $5.48 \mathrm{de}$ & $3.37 \mathrm{jk}$ & 3.0 & 25.041 & $25.19 \mathrm{k}$ \\
\hline & & & $246.60 \mathrm{c}$ & $21.58 \mathrm{~b}$ & $21.84 \mathrm{~b}$ & $5.73 \mathrm{ab}$ & $5.76 \mathrm{bc}$ & $\begin{array}{c}3.76 \\
\text { defgh }\end{array}$ & 3.79 ef & $30.28 \mathrm{~d}$ & $\begin{array}{c}30.93 \\
\text { cd }\end{array}$ \\
\hline & & As. acid & $258.35 \mathrm{a} 254.11 \mathrm{a}$ & $23.44 \mathrm{a}$ & $25.18 \mathrm{a}$ & $5.92 \mathrm{a}$ & $5.98 \mathrm{a}$ & 3.96 cde & $\mathrm{bc}$ & $34.29 \mathrm{a}$ & $33.99 \mathrm{a}$ \\
\hline & & $\mathrm{Co}$ & 163.26 r 176.61 o & $13.91 \mathrm{k}$ & 13.031 & $\begin{array}{l}3.73 \\
\operatorname{lmn}\end{array}$ & $3.98 \mathrm{ij}$ & fgh & $\mathrm{ij}$ & 21. & $1 \mathrm{p}$ \\
\hline & 泀 & Sa. acid & $\begin{array}{cc}186.11 & 198.59 \mathrm{j}\end{array}$ & j 16.64 i & $17.55 \mathrm{ef}$ & $4.56 \mathrm{hi}$ & $4.15 \mathrm{i}$ & 3.64 fghi & $4.23 \mathrm{bc}$ & $26.91 \mathrm{i}$ & $26.27 \mathrm{i}$ \\
\hline & & A & $206.26 \mathrm{i} 212.10 \mathrm{~g}$ & $18.39 \mathrm{~g}$ & $1955 \mathrm{~cd}$ & fgh & $4.73 \mathrm{~g}$ & de & $3 c$ & 28. & 0 \\
\hline \multirow{6}{*}{ 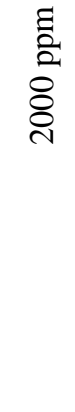 } & \multirow{3}{*}{ 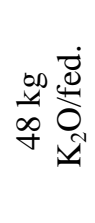 } & trol & $193.271199 .62 \mathrm{j}$ & $6.44 \mathrm{i}$ & $15.15 \mathrm{i}$ & $4.65 \mathrm{gh}$ & $4.76 \mathrm{~g}$ & $3.53 \mathrm{hij}$ & $3.18 \mathrm{jkl}$ & $23.47 \mathrm{n}$ & 24.75 \\
\hline & & Sa. & $\begin{array}{c}212.04 \\
\mathrm{gh}\end{array} 223.30 \mathrm{f}$ & $19.92 \mathrm{de}$ & $20.07 \mathrm{c}$ & $5.29 \mathrm{c}$ & $5.62 \mathrm{~cd}$ & $\begin{array}{l}3.76 \\
\text { defgh }\end{array}$ & $3.56 \mathrm{gh}$ & $28.92 \mathrm{f}$ & 29.58 \\
\hline & & A & $230.02 \mathrm{e}^{237.21} \mathrm{~cd}$ & $20.33 \mathrm{~d}$ & $21.43 b$ & $5.57 \mathrm{~b}$ & $5.74 \mathrm{c}$ & 3.65 fghi & $3.73 \mathrm{efg}$ & $31.74 \mathrm{c}$ & $31.91 \mathrm{~b}$ \\
\hline & \multirow{3}{*}{ 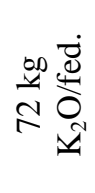 } & Control & $203.79 \mathrm{j} 191.66 \mathrm{k}$ & $17.37 \mathrm{~h}$ & $16.31 \mathrm{~h}$ & $5.07 \mathrm{cde}$ & $5.43 \mathrm{e}$ & $3.42 \mathrm{ijk}$ & $3.00 \mathrm{mn}$ & $30.02 \mathrm{de}$ & $25.67 \mathrm{j}$ \\
\hline & & cid & $243.53 \mathrm{~d} 235.2$ & $121.06 \mathrm{bc}$ & $21.80 \mathrm{~b}$ & $5.77 \mathrm{ab}$ & $5.70 \mathrm{c}$ & 3.65 fghi & $3.82 \mathrm{de}$ & $33.65 \mathrm{~b}$ & $\begin{array}{c}30.65 \\
\text { de }\end{array}$ \\
\hline & & & 256.27 b 250.75 & $22.95 \mathrm{a}$ & $24.83 \mathrm{a}$ & $5.82 \mathrm{ab}$ & $5.94 \mathrm{ab}$ & 3.94 cde & $4.18 \mathrm{bc}$ & 25.26 & 33.71 \\
\hline
\end{tabular}




\section{References}

Abd Allah, E. M.; M. A. ISSA; S. M. Abd ElKader; H. S. Abd El-Salam and W. M. Abd El-Hakim (2007). Effect of some antioxidants treatments on yield, some chemical constituents and antinutritional factors of some vegetable legumes. $1^{\text {st }}$ Intr. Conf. Desert Cultivation Problems \& Solutions, Minia Univ., 27-29 March.

Abd El-Baky, M. M. H.; A. A. Ahmed; M. A. ElNemr and M. F. Zaki (2010). Effect of Potassium Fertilizer and Foliar Zinc Application on Yield and Quality of Sweet Potato. Research Journal of Agri. and Biol. Sci., 6: 386-394.

AL-Easily, I. A (2002). Response of some sweet potato cultivars to different agricultural treatments under sandy soil conditions. M. Sc. Theisis, Fac. Agric., Zagazig Univ., Egypt.

Arisha, H. M. (2000). Effect of Vitamin C on growth, yield and tuber quality of some potato cultivars under sandy soil conditions. Zagazig J. Agric. Res., 27: 91-104.

Bardisi, A. (2004). Influence of vitamin $C$ and Salicylic acid foliar application on garlic plants under sandy soil condition. 1. Growth and plant chemical composition. Zagazig J. Agric. Res., 31: 1337-1348.

Black, C. A. (1965). Methods of soil analysis. Part 2. Amer. Soci. Agron. INC. Publisher, Madison, Wisconsin, USA.

Blokhina, O.; E. Virolainen and K. V. Fagerstedt (2003). Antioxidant, oxidative damage and oxygen deprivations stress. A Review Ann. Bot., 91: 179-194.

Byju, G. and J. George (2005). Potassium nutrition of sweet potato. Adv. Hort. Sci., 19: 221-239.

Chakrabarty, A.; H. Sen and S. B. Goswami (1993). Growth and sink potential of sweet potato cultivars as influenced by potassium nutrition both under rainfed and irrigated conditions. J. Potass. Res., 9: 55-61.

Clough, G. H. (1994). Potato Tuber Yield, Mineral Concentration, and Quality after Calcium Fertilization. J. Amer. Soc. Hort. Sci., 119: 175179.

Dkhil, B. B.; M. Denden and S. Aboud (2011). Foliar Potassium Fertilization and its Effect on Growth, Yield and Quality of Potato Grown under Loam-sandy Soil and Semi-arid Conditions. Inter. J. Agri. Res., 6: 593-600.

El-Morsy, A. H. A.; A. S. Ezzat and U. M. Saif El-Deen (2010). Effect of some phosphorus and potassium rates and foliar spray with antioxidants on growth, yield and yield quality of garlic (Allium sativum L.). Annals of Agric. Sc., Moshtohor. 48: 27-40.
El-Sayed, H. A. (1991). Growth and yield of potatoes as affected by CCC, GA and vitamin C. J. Agric. Sci. Mansoura Univ., 16: 648-652.

El-Sherbini, M. A. A. (2011). Some agronomical practices for improving tomato (Lycopersicon esculentum Mill) productivity under high temperature conditions. M. Sc. Thesis, Fac. Agric. Mansoura Univ., Egypt.

Gad El-Hak, S. H.; I. Y. T. Abd El-Mageed; A. A. Galal; N. S. Youssef and A. Z. Osman (2002). Influence of antioxidants and calcium chloride on potato growth and yield. Proc. Minia $1^{\text {st }}$ Conf. For Agric. \& Environ. Sci., Minia, Egypt, Marc. 25-28.

Gashti, A. H.; M. N. S. Vishekaei and M. H. Hosseinzadeh (2012). Effect of potassium and calcium application on yield, yield components and qualitative characteristics of peanut (Arachis hypogaea L.) in Guilan Province, Iran. World App. Sci. J., 16: 540-546.

George, M. S.; L. GuoQuan and Z. WeiJun (2002). Genotypic variation for potassium uptake and utilization efficiency in sweet potato (Ipomoea batatas L.). Field Crops Res., 77 (1): 7-15.

Gowda, P. H. R.; H. B. Lingaiah; K. Seenappa and K. T. Shivashankara (1990). Effect of potassium application on yield and yield components of sweet potato. J. Potass. Res., 6: 79-81.

Grang, G. R. (1963). United State standards for grades of sweet potatoes. USDA-ARS. Washington D.C.

Hayat, S. and A. Ahmad (2007). Salicylic acid: A Plant Hormone. Published by Springer, P. O. Box 17, 3300 AA Dordrecht, The Netherlands. p 410.

Imas, P. (1999). Integrated Nutrient Management in Potato. In: Proceeding of IPI Global Confrence on potato New Delhi India., Dec. 6-11.

Jackson, M. L. (1967). Soil chemical analysis. Prentice-Hall of India, Newdelhi, India. P. 115.

JianWei, L.; C. Fang; X. YouSheng; W. YunFan and L. DongBi (2001). Sweet potato response to potassium. Better Crops International. 15: 10-12.

Koller, H. R. (1972). Leaf area- leaf weight relationship in the soybean canopy. Crop Sci., 12: $180-183$.

Lang, N. S.; R. G. Stevens; R. E. Thornton; W. L. Pan and S. Victory (1999). Potato nutrient management for central Washington. EB1871. Published February 1999. Subject code 274. A.

Lin, K. H.; Y. K. Chiou; S. Y. Hwang; L. F. O. Chen and H. F. Lo (2008). Calcium chloride enhances the antioxidative system of sweet potato (Ipomoea batatas) under flooding stress. Annals of Applied Biology. 152 (2): 157-168.

Marschner, H. (2013). Mineral nutrition of higher plants $\left(3^{\text {th }}\right.$ ed.) Academic Press, London, p. 285299. 
Mengel, K. and E. A. Kirkby (1987). Principles of plant nutrition, Publisher: International Potash Institute. Long Druck AG. Liebefeld/Bern, pp 203-210.

Moran, R. (1982). Formulae for determination of chlorophylous pigments extracted with $\mathrm{N}, \mathrm{N}-$ Dimethyl formamide. Plant physiol. 691: 13761381.

Mukhopadhyay, S. K. and P. K. Jana (1990). Economics of potassium fertilization in sweet potato. J. Potass. Res., 6: 114-118.

Mukhopadhyay, S. K.; H. Sen and P. K. Jana (1992). Effect of potassium on growth and yield of sweet potato. J. Root Crops. 18: 10-14.

Munne-Bosch, S. (2005). The role of $\alpha$-tocopherol in plant stress tolerance. J. plant physio. 162: 743-748.

Njiti, V. N; Q. Xia; L. S. Tyler; L. D. Stewart; A. T. Tenner; C. Zhang; D. Alipoe; F. Chukwuma and M. Gao (2013). Influence of Prohexadione Calcium on Sweet potato Growth and Storage Root Yield. HortSci. J., 48: 73-76.

Orabi, S. A. and B. B. Mekki (2008). Root yield and quality of sugar beet (Beta vulgaris L.) in response to ascorbic acid and saline irrigation water. Ameri.Eurasian J. Agric. and Enviro. Sci., 4: 504-513.

Prasad, U. K.; T. N. Prasad; S. Narayan and A. Kumar (1997). Effect of soil moisture regimes on sweet potato yield, potassium balance and water use efficiency. J. Potass. Res., 13: 283289.

Reddy, A. S. N. (2001). Calcium: silver bullet in signaling. Plant Sci., 160: 381- 404.

Schmitz-Eiberger, M.; R. Haefs and G. Noga (2002). Calcium deficiency-influence on the antioxidative defense system in tomato plants. J. Plant Physiol. 159: 733-742.

Snedecor, G. W. and W. G. Cochran (1980). Statistical methods. $7^{\text {th }}$ Ed. Iow State Univ. Press, Iowa, USA.

Sulaiman, H.; O. Sasaki; T. Shimotashiro; N. Chishaki and S. Inanaga (2004). Effect of Calcium Concentration on the Shape of Sweet Potato (Ipomoea batatas L.) Tuberous Root. Plant Prod. Sci., 7: 191-194.

WenYing, Y.; W. WeiYing; Q. YongXiang; K. YuQin; W. Wei and C. ZhiDong (2008). Salicylic acid induced sweet potato resistance to Ralstonia solanacearum through antioxidant enzymes. J. Fujian Agric. and Forestry Univ. (Natu. Sci. Ed.). 37: 23-26.

Woolfe, J. A. (1992). Sweet potato: an untapped food resource. New York: Cambridge University Press.

WuZhong, N.; Z. YongSong; L. XianYong (1997). The effect of different $K$ sources on yield and quality of some vegetable crops. Acta Agric. Zhejiangensis. 9: 143-148. 
تأثير الكالسيوم والبوتاسيوم ويعض مضادات الأكسدة على النمو والمحصول والقدرة التخزينية فى البطاطا: 1- النمو الخضرى والمحصول وصفات الجذور الارنية.

سمير كامل الصيفى '، محمود عبد المحسن حسن ، سوسن محمد حسن سرج1 ، أسامة محمد سيف الاين ومحمد احمد محمد على.

$$
\begin{aligned}
& \text { 1- قسم البساتين- كلية الزراعة بالأسماعيلية- جامعة قناة السويس. } \\
& \text { 2- قسم بحوث الخضر - معهد بحوث البساتين - مركز البحوث الزراعية- الجيزة. }
\end{aligned}
$$

أجريت تجربتان حقليتان فى مزرعة البرامون للبحث الزراعى الثابعة لمحطة بحوث البساتين بالمنصورة خلال موسمى الزراعة الصيفى (

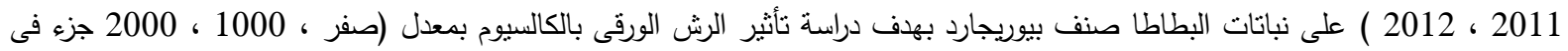

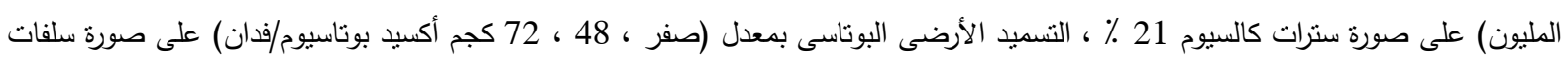

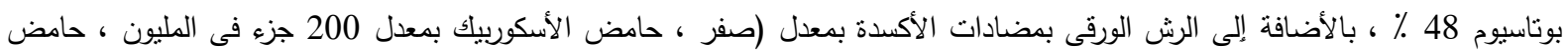

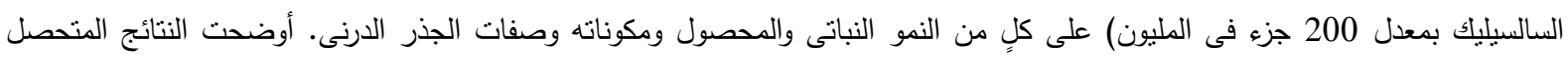

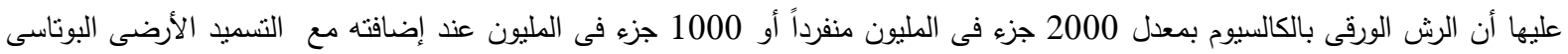

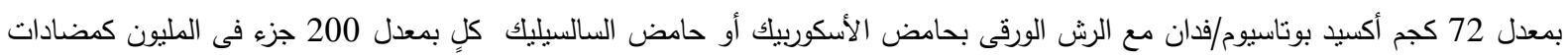

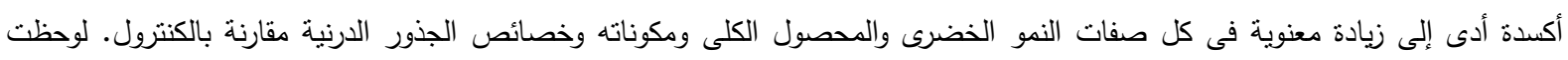

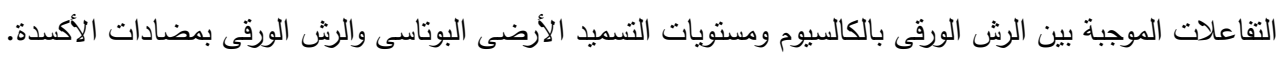

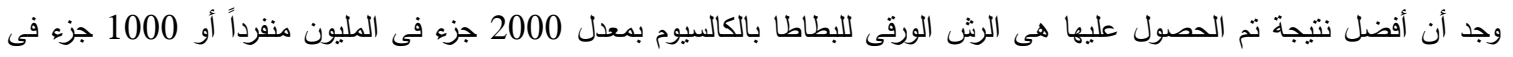

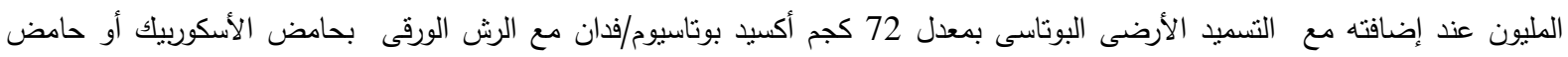
السالسيليك كلٍ بمعدل 200 جزء فى المليون كمضادات أكسدة. 